Article

\title{
The Mainstreaming of NBS in the SECAP of San Donà di Piave: The LIFE Master Adapt Methodology
}

\author{
Filippo Magni ${ }^{1}$, Francesco Musco ${ }^{1}$, Giovanni Litt ${ }^{2, *}$ and Giovanni Carraretto ${ }^{2}$ \\ 1 EPiC Earth and Polis Research Centre, Department of Architecture and Arts, Iuav University of Venice, \\ 30135 Venice, Italy; filippo.magni@iuav.it (F.M.); francesco.musco@iuav.it (F.M.) \\ 2 Department of Architecture and Arts, Iuav University of Venice, 30135 Venice, Italy; \\ giovanni.carraretto@iuav.it \\ * Correspondence: giovanni.litt@iuav.it; Tel.: +39-348-46-38-971
}

Received: 23 October 2020; Accepted: 29 November 2020; Published: 3 December 2020

\begin{abstract}
Climate change is a global phenomenon that poses local risks to sectors across society and the economy. All these growing risks have led the Municipality of San Donà di Piave-located within the Metropolitan City of Venice (CMVe) - to strengthen, over the years, its commitment to the adaptation to climate change in its plans and policies. Nature-based solutions can offer a perfect example of sustainable solutions to cope with climate change mitigation and adaptation challenges. In this context, thanks to the support of the LIFE Master Adapt project, San Donà di Piave, applying its methodologies and creating new territorial information, was able to insert, within its Action Plan for Sustainable Energy and Climate (SECAP), important and structural Nature-Based Solutions (NBSs) for the entire municipal area. This experience demonstrates how this process of mainstreaming adaptation actions and NBSs is possible at all levels of government of the territory. It also highlights the virtuosity of replicability in other contexts of the CMVe and the transition from theoretical concepts to concrete actions (NBSs) for adaptation into existing plans. This process happened with a climate-proof modification of the existing planning attitude, whether mandatory or voluntary.
\end{abstract}

Keywords: climate change policies implementation; adaptive governance; implementation tools

\section{Introduction}

The Metropolitan City of Venice (CMVe), located within the Veneto Region, is an area historically linked to the dynamics of anthropogenic management of environmental resources [1]. This area is nowadays very sensitive to the increasing climatic changes due to global warming. Its strong exposure to the impacts of climate change is the result of territorial processes that have contributed over time to generate a high consumption of land. The consequence of this process-and its relationship with a territory which for a large part is below sea level—has significantly increased its hydraulic hazard [2].

The combination of these factors has also gradually reduced the absorption capacity of water flows by land during intense weather events. This leads to a consequent increase in stagnation, urban flooding and potential flooding of watercourses [3]. In addition to the anthropogenic component, in the CMVe, also the question of sea-level rise gains importance. Its effects are visible particularly in the lower Veneto plain which is also subject to the phenomenon of subsidence [4].

The focus of this research was born within the LIFE Master Adapt project, cofinanced by the LIFE Program. Within the CMVe, the pilot area chosen by the project is formed by the three municipalities of San Donà di Piave, Eraclea and Jesolo. Only the Municipality of San Donà di Piave is considered for this article. Taking this case study, the article wants to propose a methodology for medium-sized municipalities for the mainstreaming of adaptation actions and nature-based solutions within municipal planning. 
As Figure 1 shows, in the CMVe, the Municipality of San Donà di Piave is located, for the most part, below sea level. Therefore, the area is constantly monitored and kept drained by the Consorzio di Bonifica Veneto Orientale (Eastern Veneto Reclamation Consortium). Due to the high soil consumption, in the context of a "widespread city" [5] with numerous productive settlements, the Municipality of San Donà di Piave is easily subject to flooding (the most serious recent flood took place between the end of October and the beginning of November 2010, when Veneto was hit by a violent wave of bad weather. It was no less important than the most recent flood in November 2019) (Figure 2).
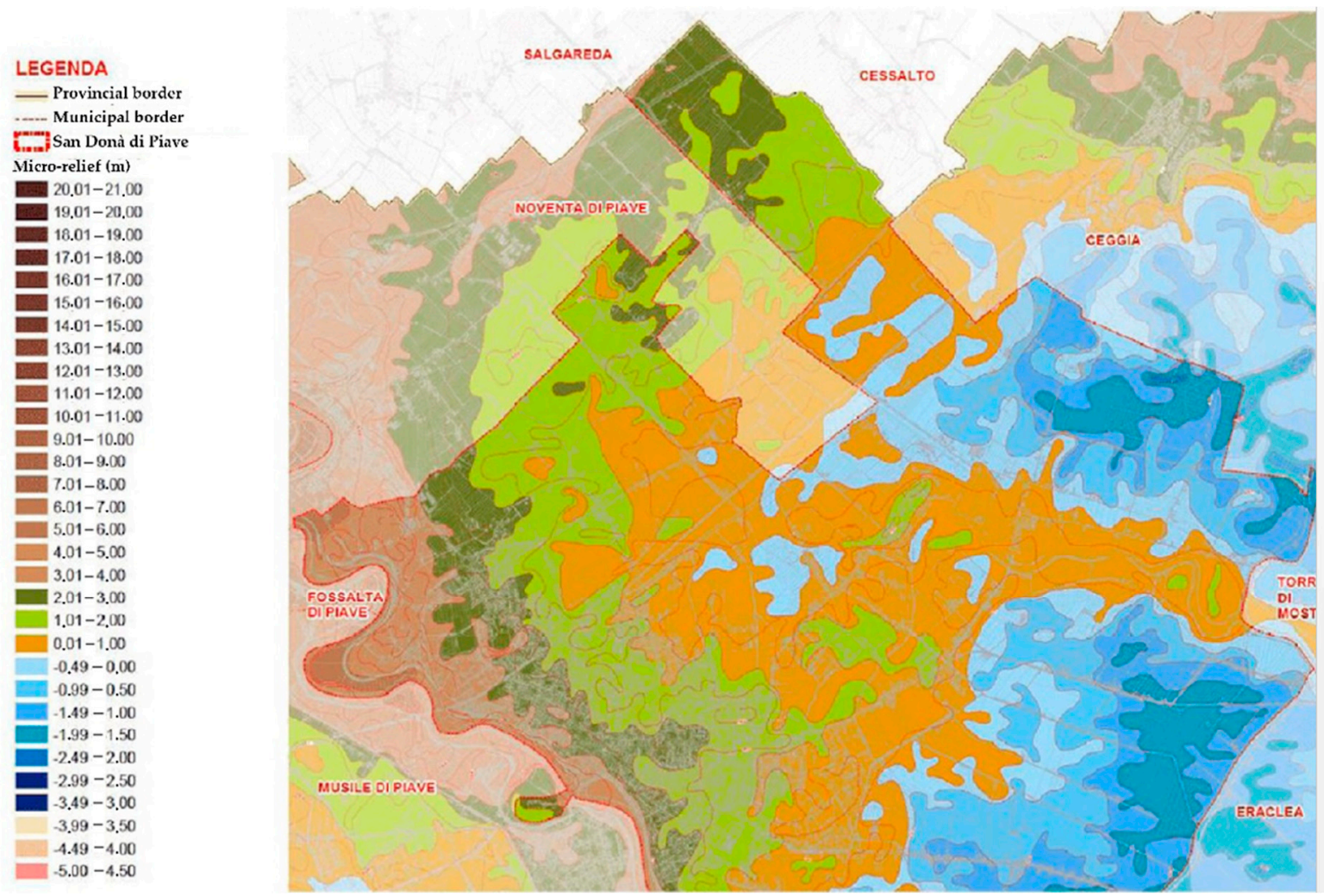

Figure 1. Emergency plan of the Metropolitan City of Venice. Altimetric micro-relief table.

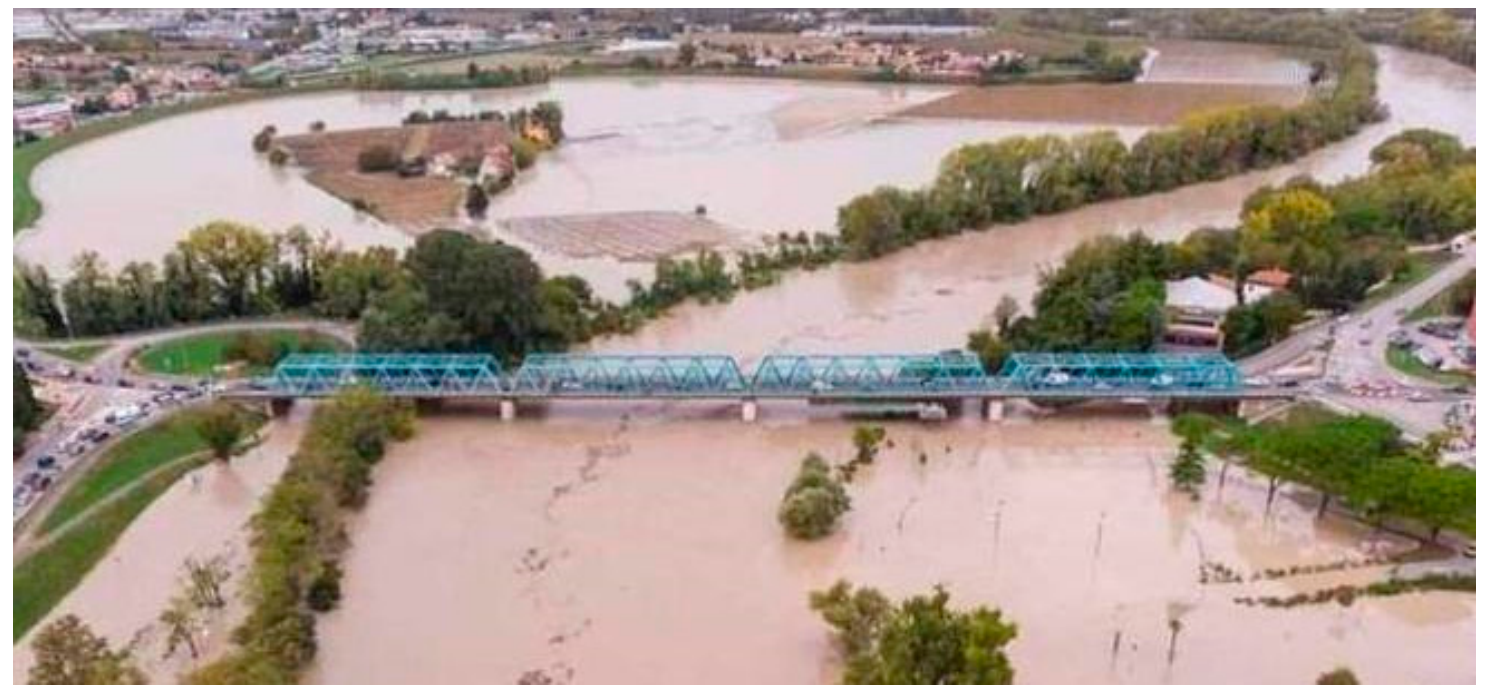

Figure 2. The November 2019 flood that flooded part of the territory of San Donà di Piave. 
All these growing risks have led the Municipality of San Donà di Piave to strengthen over the years its commitment to the adaptation to climate change in municipal plans and policies.

The Municipality of San Donà di Piave is suffering from increasing impacts of climate change in terms of quantity and intensity. This vast area can be the territorial application of European and national strategies that are developing around adaptation issues. While mitigation acts on the global scale, adaptation must take shape in localized responses to specific impacts. The guidelines provided by large-scale strategies must be translated into territorial actions.

This downscaling took place in the CMVe thanks to the LIFE Master Adapt project which provided the pilot municipalities with the opportunity to mainstream Nature-Based Solutions (NBSs) and adaptation actions to implement actions in response to local needs. This has happened without forgetting the awareness of acting in a broad legislative and strategic context.

The transversal adaptation proposed by LIFE Master Adapt has led to a renewal of territorial policies in the pilot municipalities and in particular in the Municipality of San Donà di Piave that will be deepened.

Indeed, local climate change adaptation and mitigation policies cannot be isolated from the over-ordered regulatory contest-regional, national, or European-that is emerging to provide solutions and approaches to respond to the climate crisis.

At the European level, different instruments support local and regional administrations in climate commitment-the most important is the EU Climate Change Adaptation Strategy [6]. The strategy starts from the assumption that the consequences of climate change are increasingly tangible in Europe due to the increase in average global temperature, compared to the pre-industrial period. This involves a change in natural processes, quality of life, precipitation dynamics, etc. To ensure the quality of life of Europeans by irreversible consequences on a large scale, the European Union has decided to place the climate struggle at the center of its action. This happened to contain global warming to lower than $2{ }^{\circ} \mathrm{C}$ above pre-industrial period levels as determined by the Paris Agreement [7]. The European Strategy was born after a phase of listening to scientific, institutional and all stakeholders coordinated by the Euro-Mediterranean Centre on Climate Change (CMCC) [8]. In addition to the European Strategy, the European Green Deal [9], the European Climate Law [10] and the Sustainable Europe Investment Plan [11] are of great interest. These instruments help to support choices against climate change in both the public and private worlds.

The European Strategy has generated national strategies, which decline at the national level, with the necessary contextualizations, the European goals. In Italy, this phase of framing was made thanks to a "Report on the state of scientific knowledge on impacts, vulnerability, and adaptation to climate change in Italy", an "Analysis of Community and national legislation relevant to impacts, vulnerability, and adaptation to climate change" and the "Elements for a National Strategy of Adaptation to Climate Change". These documents led to the National Strategy of Adaptation to Climate Change (SNACC) [12] and the National Climate Change Adaptation Plan (PNACC) [13]. These two documents have provided the basis for defining the matrix objectives scaled territorially from what is indicated at the national level and have accompanied the definition of sustainable proposals in all its meanings-social, environmental and economic [14].

Otherwise, public policies against the effects of climate change, both nationally and locally, in Europe have, over the years, given priority to mitigation over adaptation [15]. Perhaps this also happened for the urgent convenience of economic savings [16-19]. Differently, adaptation-intended to be the process of adaptation to the current or expected climate and its impacts [20]—is difficult to carry out systematically [21]; in Italy, compulsory urban plans for adaptation to climate change are not proposed for municipalities (except for two cities, Ancona (Marche region) and Bologna (Emilia Romagna region) which have specific plans). While 4989 municipalities have joined the Covenant of Mayors (adopting 3216 mitigation-oriented Sustainable Energy Action Plans - SEAPs), only 981 cities have joined the new Covenant of Mayors for Climate \& Energy (adopting 551 Sustainable Energy and Climate Action Plans-SECAP—with indications for climate adaptation) [22]. This behavior occurs 
mainly due to the lack of a national cogency for the implementation of policies aimed at mitigating or adapting to climate change. A further problem is a transition from interventions that proceed "by projects", often defined by the timing and modalities of sectoral policies, to "per processes" [23]. It is, therefore, necessary to define planning arrangements that are guided by clear goals which are set as a result of a spatial analysis phase.

In this context, the LIFE Master Adapt project has the purpose of developing an operational methodology so that regions, metropolitan cities, municipalities and groups of municipalities can mainstream adaptation measures to climate change into their plans and programs as a key element for the security of their territory. According to the project, "mainstream" refers to the inclusion of climate actions in programs, policies, or management strategies already established or in the process of being implemented, rather than separately developing activated adaptation and mitigation initiatives. This can happen so that adaptation and mitigation to climate could change to become sustainable and applicable on a large scale.

This contribution demonstrates starting from the analysis of territorial vulnerabilities, how an effective process of flood risk prevention should be based on the definition of specific goals and how specific measures (specifically nature-based solutions) should be included in the plans.

The Municipality of San Donà di Piave applied the methodologies built by the Master Adapt project and created new territorial information. In this way, the municipality was able to insert, within its Action Plan for Sustainable Energy and Climate (SECAP) — the new Covenant of Mayors for Climate and Energy which commits municipalities to share a long-term vision for 2050 by accelerating the decarbonization of territories and strengthening the ability of cities to adapt to the effects of climate change-important and structural nature-based solutions (NBSs), such as adaptation actions to the expected climatic impacts for the entire municipal area.

These measures, systematized into the SECAP, have also involved other territorial management tools, such as: the Water Plan, actions both of the Consortia of the Basin Imbrifero Montano del Basso Piave (BIM Piave) and the Consortia Bonifica Veneto Orientale and the Three-Year Plan of Public Works. This success demonstrated the effectiveness of the mainstreaming process.

The definition of the solutions for the Municipality of San Donà di Piave considered: the socio-economic context and needs, the impacts analyzed for the territory and also the historical knowledge of local authorities on water management in a territory that lives on the regulation of water flows and land reclamation. So, nature-based solutions have been an important field of action and mainstreaming in San Donà di Piave. Indeed, NBSs use ecosystems and their services to address societal challenges. This contribution focuses on climate change and adaptation planning challenges, but also food security or natural disasters are important to be considered. The International Union for Conservation of Nature defines NBSs as "Actions to protect, sustainably manage and restore natural or modified ecosystems that address societal challenges effectively and adaptively, simultaneously providing human well-being and biodiversity benefits" [24]. Additionally, the European Commission defines NBSs as: "Living solutions inspired by, continuously supported by and using Nature designed to address various societal challenges in a resource-efficient and adaptable manner and to provide simultaneously economic, social and environmental benefits" [25]. In the environmental sciences and the nature conservation contexts, international organizations, such as International Union for Conservation of Nature - IUCN and the World Bank [26], began to search for solutions suitable for ecosystems rather than conventional engineering interventions, aiming to adapt and mitigate climate change effects, while improving sustainable livelihoods and protecting natural ecosystems and biodiversity [27].

It is useful to be reminded that the concept of NBS is based on some principles [28], as follows:

- embrace nature conservation norms and principles;

- can be implemented alone or in an integrated manner with other solutions to societal challenges (e.g., technological and engineering solutions); 
- determined by site-specific natural and cultural contexts that include traditional, local and scientific knowledge;

- produce societal benefits fairly and equitably, in a manner that promotes transparency and broad participation;

- maintain biological and cultural diversity and the ability of ecosystems to evolve;

- $\quad$ are applied at a landscape scale;

- recognize and address the trade-offs between the production of a few immediate economic benefits for development and future options for the production of the full range of ecosystem services;

- are an integral part of the overall design of policies and measures or actions, to address a specific challenge.

It is also demonstrated that nature-based solutions are a fundamental part of the action for climate and to defend urban biodiversity. Indeed, NBS can provide over one-third of the cost-effective climate mitigation needed until 2030 to stabilize global warming to below $2{ }^{\circ} \mathrm{C}$. Additionally, NBSs can contribute to the creation of new jobs, increment resilience, reduce people's poverty, support ecosystem services, biodiversity and access to freshwater [29]. United Nations (UN) Climate and Sustainable Development Agendas, together with the Sustainable Development Goals (SDGs)(SDG \#13 “Take urgent action to combat climate change and its impacts", SDG \#15 "Protect, restore and promote sustainable use of terrestrial ecosystems, sustainably manage forests, combat desertification, and halt and reverse land degradation and halt biodiversity loss"), promote NBSs, with the following goals:

- Increase and mainstream NBSs within national, regional and local governance;

- Enhance regional cooperation, in ways that encourage ambition, transparency and environmental integrity;

- Generate the shifts needed in both domestic and international governance and finance to realize the potential of NBS;

- Scale-up NBS for mitigation, resilience and adaptation in key areas, ensuring people's livelihoods in the face of climate threats [29].

The SECAP of San Donà di Piave took account of these indications to mainstream solutions into its plans. Given the territorial context and the analyses produced, in the case study of San Donà, the orientation of the plan is coherent with the approach and indications of the major global documents cited above referring to NBS; in particular, the context is densely characterized by natural elements, which have been used to face with the studied climate impacts.

The present contribution, through the exemplary case of the SECAP of San Donà di Piave, highlights how the NBSs (understood as measures and not as an approach) have been included in the instruments of territorial planning thanks to the process of mainstreaming activated by the project LIFE Master Adapt.

The experience of San Donà di Piave also demonstrates how the process of mainstreaming of adaptation actions and NBSs is possible at all levels of government of the territory. This experience also highlights the virtuosness of replicate the mainstreaming in other contexts of the CMVe and the possibility of the transition from theoretical concepts to concrete actions (e.g., NBS) for adaptation into existing plans. This process happened with a climate-proof modification of the existing planning attitude, whether mandatory or voluntary.

\section{Materials and Methods}

\subsection{LIFE Master Adapt}

The LIFE Master Adapt project [30] has developed a common methodology to support regions (Lombardia and Sardinia), metropolitan cities (Venice and Cagliari) and groups of municipalities (North Milan and North Salento) in the pilot areas (Figure 3) to identify key vulnerabilities to climate change and to develop strategies for the governance of adaptation in urban areas. 


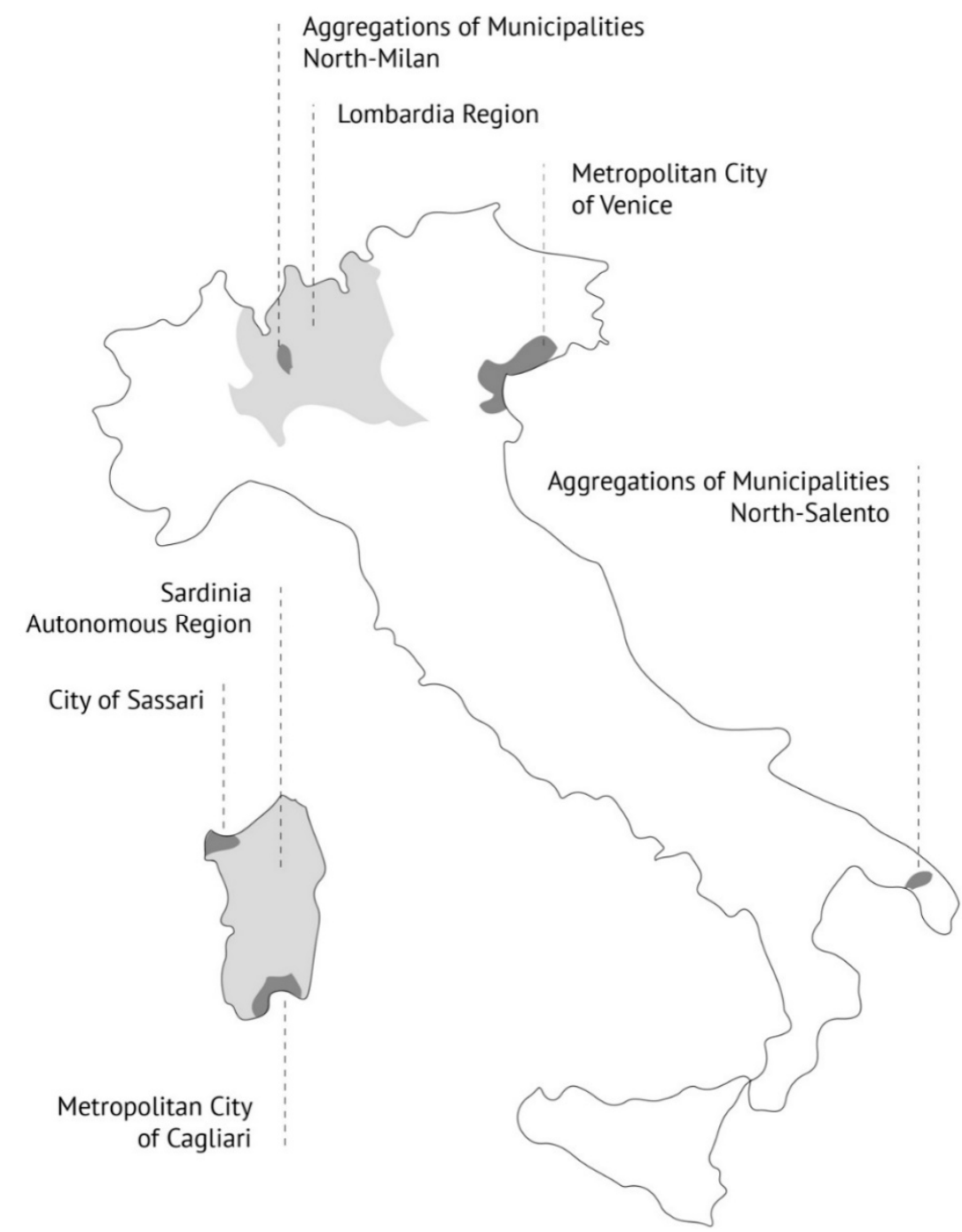

Figure 3. Pilot areas of the project LIFE Master Adapt: Lombardi and Sardinia Region, Metropolitan City of Venice and Cagliari, aggregation of municipalities North Milan and North Salento, City of Sassari.

Thanks to 3 years of research and fieldwork, the project developed tools to facilitate the optimization of the connection with the planning of a higher level, to increase and coordinate municipal planning capacity and facilitate public-private collaboration. This activity was accompanied by the process of mainstreaming for the design and implementation of adaptation actions and strategies through coordination between the different levels of government of the territory-state, regions and local authorities—and horizontal coordination between different policies-territorial, landscape, agricultural, environmental, civil protection, etc.

LIFE Master Adapt is articulated in the following phases:

- climate analysis and vulnerability assessment at the regional level to identify climate change impacts, risks and vulnerabilities for key sectors and provide indicators and guidelines for climate analysis and vulnerability assessment at regional and local levels;

- assessment of mainstreaming processes in climate change adaptation practices selected from those already in place at the European level, to create a European network and capitalize on experiences;

- definition of adaptation objectives at the regional and sub-regional level, following a process of vertical and horizontal mainstreaming, by aligning and aligning adaptation policies at different levels; 
- developing effective methods for multi-level integration and governance in the definition of regional and sub-regional adaptation strategies;

- integration of the adaptation strategy and the measures identified, at the intermediate administrative level—groups of municipalities and metropolitan cities;

- replicate and transfer project results to other regions and municipalities.

\subsection{From LIFE Master Adapt to the Declination in the Municipality of San Donà di Piave}

The Municipality of San Donà di Piave has used the results of the project-both scientific analysis and methodology - to address territorial planning towards adaptation to climate change and mainstreaming of NBSs in its plans and programs (Figure 4).

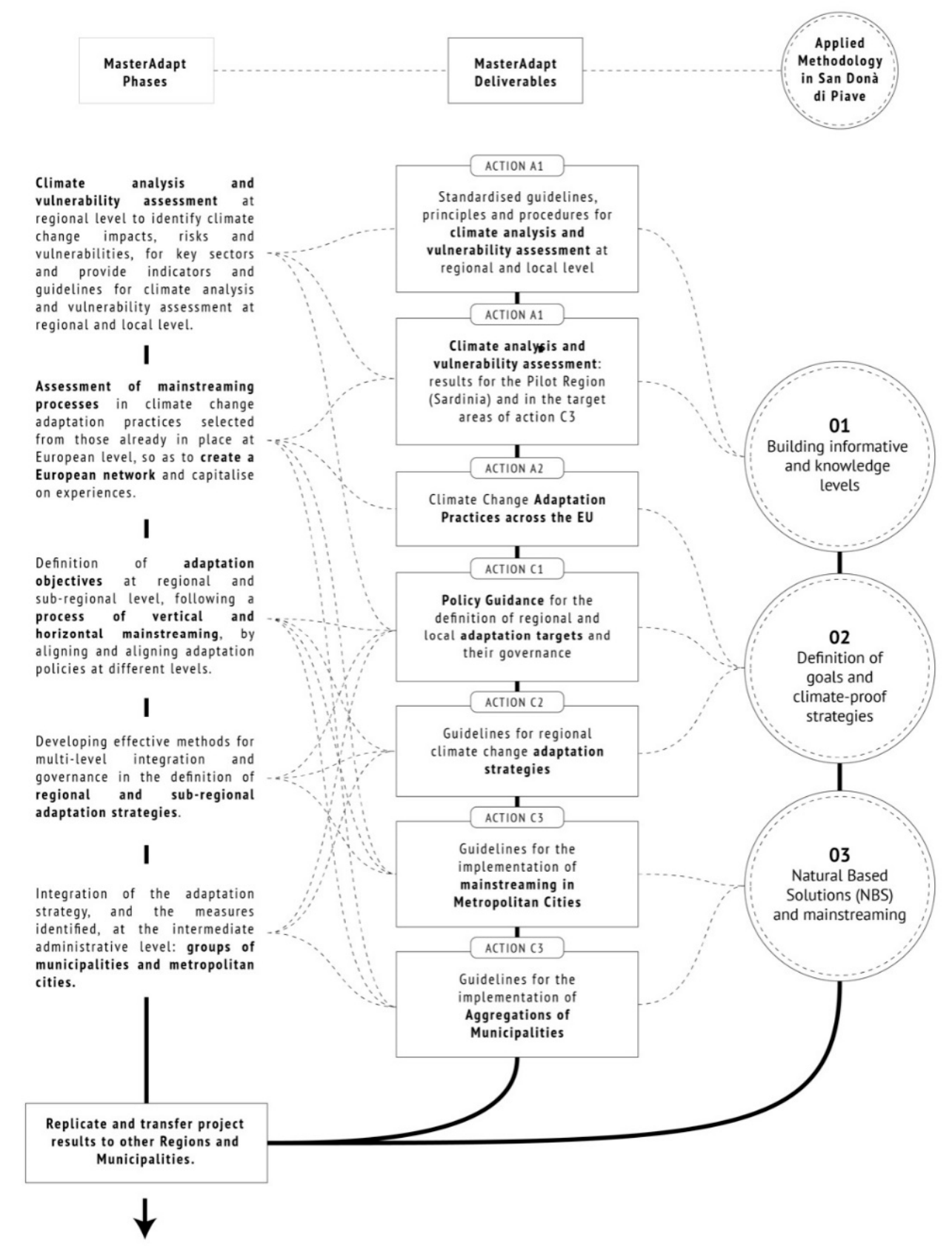

Figure 4. Correlation between LIFE Master Adapt phases, deliverables and the methodology applied to San Donà di Piave. 
The deliverables and the project results were used for the SECAP of San Donà di Piave in all phases. The methodology implemented for the Municipality of San Donà di Piave (Figure 5) takes up that of the LIFE Master Adapt project. The methodology, then, has been adapted to the specific territorial context.

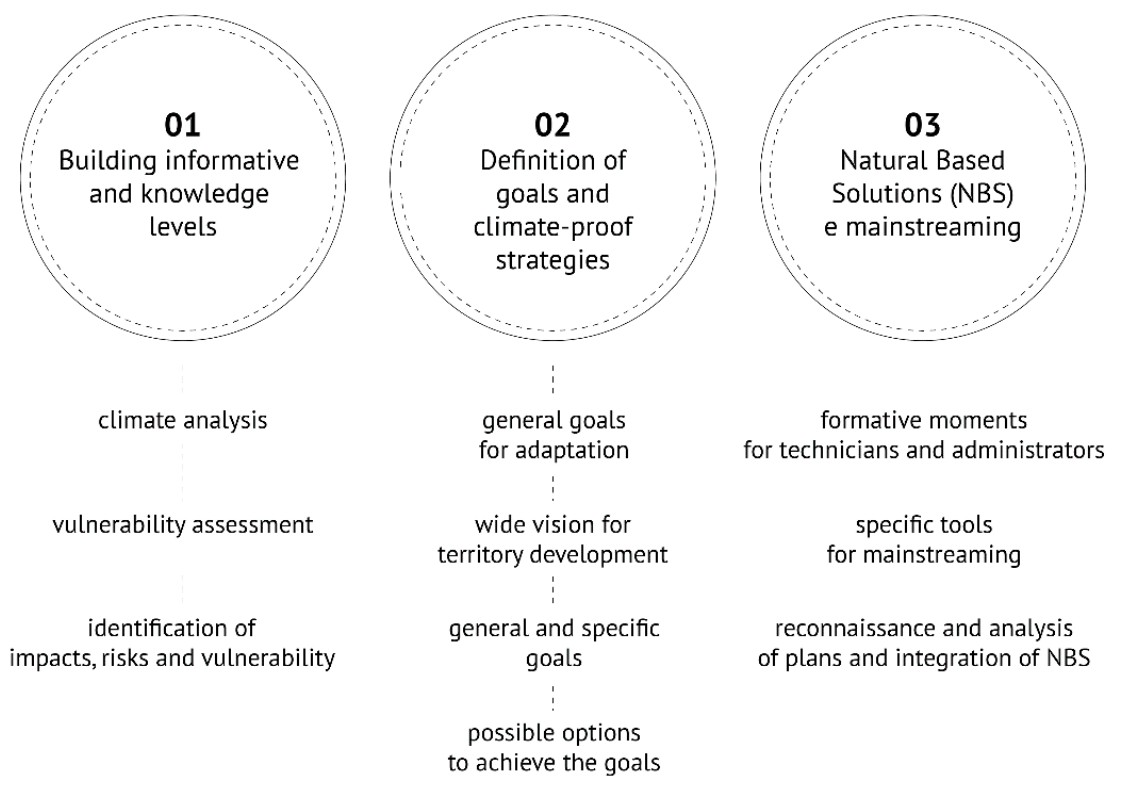

Figure 5. Methodology applied to San Donà di Piave.

The adaptation process in San Donà di Piave is synthesized in three macro-phases, as is visible in Figure 5. These are:

- definition of new information levels and new knowledge levels. This phase was made possible thanks to a climate analysis and a vulnerability assessment which identified impacts, risks and vulnerabilities from climate change for key sectors;

- support for the process that led to the definition of adaptation goals and strategies and then to the actions applied to the territory. This phase took place with a strong process of involvement of local authorities and stakeholders. In the case study, a strong bottom-up process was used which was developed with the contribution of the sectors of the municipality, the political part of the municipality and the CMVe, the scientific partners of the project. The adaptation goals of the area have been defined according to the following step: (1) definition of goals for adaptation, (2) definition of a view for the development of the territory in conditions of climate change, (3) identification of general and specific goals and (4) proposal of possible options to achieve goals;

- definition of nature-based solution and mainstreaming of specific measures in existing plans and programs. This phase was facilitated (1) by a series of training sessions for technicians and municipal administrators who were introduced to the basics of climate-proof planning, climate change, mitigation and adaptation [31], (2) by specific tools which have supported the technicians in mainstreaming, such as the "Guidelines for mainstreaming in groups of municipalities" [32] and (3) with a survey submitted to each municipality and analysis of municipal planning, looking for existing actions that deal, directly or indirectly, with adaptation to climate change. This phase has produced a state of the art and a thorough knowledge of what has already been implemented in the municipality.

These three phases allowed the integration of adaptation actions into the municipal plans and programs (Water Plan, Intervention Plan, Territory Planning Plan, etc.) coordinated by the SECAP.

The impacts of climate change in the territory of the Metropolitan City of Venice (CMVe) defined together with all the stakeholders are Urban Flooding (UF) and Urban Heat Island (UHI). The threats 
felt in the specific territory were evaluated in a participatory process, through three public workshops and a questionnaire entrusted to the municipalities concerned. The activities were set up to assess the perceptions and investigate what has already been completed in the area with regard to adaptation to climate change (nature-based solutions, forestation, Sustainable Urban Drainage Systems - SUDS, etc.). This phase was also supported by the document "Guidelines, principles and standardized procedures for climate analysis and vulnerability assessment at the regional and local level" within Action A1 [33] of the LIFE Master Adapt project.

Thanks to the methodology developed in the deliverable "Climate analysis and vulnerability assessment: results for the pilot region and in the target areas of action C3" (Action A1) of the Master Adapt project [34], climatic and vulnerability analyses were carried out with climate forecasts of the models.

The project considered two different socio-economic and emission scenarios: RCP (Representative Concentration Pathway) 4.5 (intermediate scenario) and RCP 8.5 (pessimistic scenario), analyzing temperatures and precipitation both in their average values and through extreme indices, as variations to the respective average values of the thirty years, 1971-2000 (Figure 6).

\begin{tabular}{|c|c|c|c|c|c|c|c|c|c|}
\hline \multicolumn{10}{|c|}{ Area of Venezia (Eraclea, Jesolo, San Donà di Piave) } \\
\hline \multirow{2}{*}{ Scenario } & \multicolumn{3}{|c|}{$2021-2050$} & \multicolumn{3}{|c|}{$2041-2070$} & \multicolumn{3}{|c|}{ 2061-2090 } \\
\hline & $\min$ & $\max$ & media & $\min$ & $\max$ & media & $\min$ & $\max$ & media \\
\hline \multicolumn{10}{|l|}{ RCP 4.5} \\
\hline Av. temperature $\left({ }^{\circ} \mathrm{C}\right)$ & +1.0 & +1.6 & +1.3 & +1.2 & +2.5 & +1.9 & +1.3 & +3.0 & +2.4 \\
\hline Tropical nights (days) & +18.2 & +20.9 & +19.7 & +24.7 & +36.3 & +31.6 & +28.4 & +42.3 & +36.7 \\
\hline \multicolumn{10}{|l|}{ RCP 8.5} \\
\hline Av. temperature $\left({ }^{\circ} \mathrm{C}\right)$ & +1.0 & +2.0 & +1.5 & +1.8 & +3.2 & +2.6 & +2.7 & +4.6 & +3.8 \\
\hline Tropical nights (days) & +20.2 & +23.8 & +22.4 & +33.7 & +45.0 & +40.6 & +51.8 & +71.5 & +59.1 \\
\hline $\begin{array}{l}\text { Temperature anoma } \\
\text { The values of extrem } \\
\text { is C), confirm this tre } \\
\text { island which conside } \\
\text { to high temperature }\end{array}$ & $\begin{array}{l}\text { show } ~ \\
\text { tempera } \\
\text { The cu } \\
\text { among } \\
\text { g. chilc }\end{array}$ & $\begin{array}{l}\text { quivoce } \\
\text { re indic } \\
\text { nt vuln } \\
\text { hers, in } \\
n \text { and th }\end{array}$ & $\begin{array}{l}\text { Narmin } \\
\text { such a } \\
\text { ability t } \\
\text { ators re } \\
\text { elderly }\end{array}$ & $\begin{array}{l}\text { Nith } \mathrm{cl} \\
\text { ropica } \\
\text { he eff } \\
\text { ing to }\end{array}$ & $\begin{array}{l}\text { y incre } \\
\text { ghts ( } n \\
\text { of heat } \\
\text { preser } \\
\text { ws hig }\end{array}$ & $\begin{array}{l}\text { ng val } \\
\text { ys per } \\
\text { aves a } \\
\text { of pop }\end{array}$ & $\begin{array}{l}\text { s during } \\
\text { ar when } \\
\text { the so- } \\
\text { lation gr }\end{array}$ & $\begin{array}{l}\text { ee } 21 \text { st ce } \\
\text { he minim } \\
\text { lled urbar } \\
\text { ups more } \\
\text { some are }\end{array}$ & $\begin{array}{l}\text { tury. } \\
\text { m T }>20 \\
\text { heat } \\
\text { ensitive } \\
\text { s (in red). }\end{array}$ \\
\hline
\end{tabular}

Figure 6. Scenario RCP (Representative Concentration Pathway) 4.5 and scenario RCP 8.5 in the area of Venice (Municipalities of Eraclea, Jesolo and San Donà di Piave).

\section{Results}

The results obtained can be summarized in three main outputs which are consequent and faithful to the methodology described above. The following results will be described in three different sub-sections:

- Definition of new information levels and new cognitive levels;

- Support for the process which led to the definition of adaptation goals and strategies;

- Definition of nature-based solutions and mainstreaming of specific adaptation measures in existing plans.

These outputs are the result of a linear process that led to the inclusion of NBS in the plans and programs of the Municipality of San Donà di Piave. This happened thanks to a mainstreaming process that began with the context analysis and continued with the definition of the goals toward the implementation of the actions (Figure 7). 


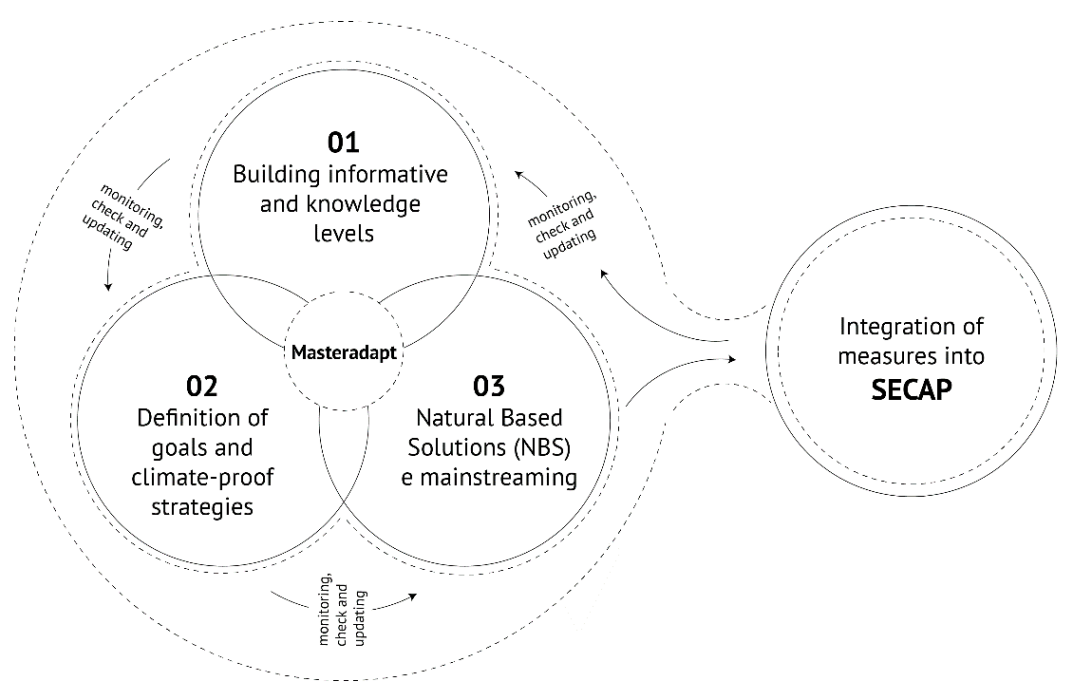

Figure 7. Master Adapt process applied in San Donà di Piave with the integration of measures in the SECAP.

\subsection{Definition of New Information Levels and New Cognitive Levels}

All the information obtained thanks to the LIFE Master Adapt project, together with the information already in possession of the municipalities and the CMVe, has created new information levels (Figure 8). These new levels have given rise to the Decision Support Tool (DST). The DST is available to political decisionmakers and municipal technicians. This phase also helped to produce, at a later stage, the document "Smart Tools: Interactive Map and Common DSS" (Action C3.2) [35].

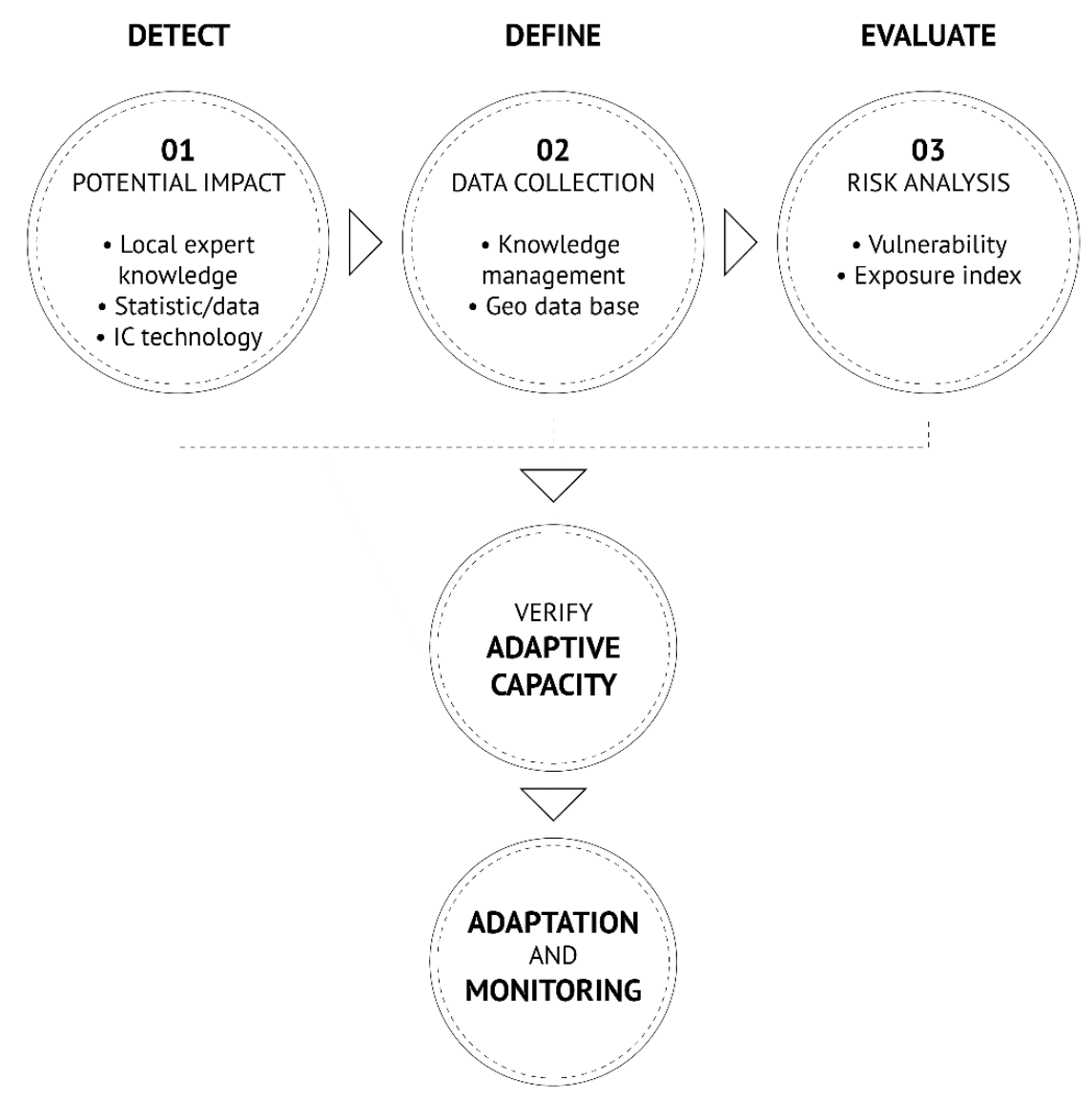

Figure 8. Methodological phases of the project LIFE Master Adapt in San Donà di Piave. 
The analysis phase for the vulnerability assessment from urban flooding made use of a quantitative-qualitative analysis based on the study of surface run-off of rainwater. The analysis highlighted how and to what extent soil waterproofing negatively affects the hydraulic performance of the area. The elaboration is useful to guide policies and strategies so that critical thresholds are not exceeded. The results obtained indicate those areas in which it is a priority to intervene with NBS, but also grey solutions, to adapt the territory. In this way, the DST permits a correct orientation of redevelopment policies, sustainable development, protection of hydraulic invariance, defense against hydrogeological risk and flooding. The analysis (Figure 9), as mentioned, was carried out for the whole CMVe with a particular focus on the municipalities of San Donà di Piave, Eraclea, Jesolo (Figure 10).

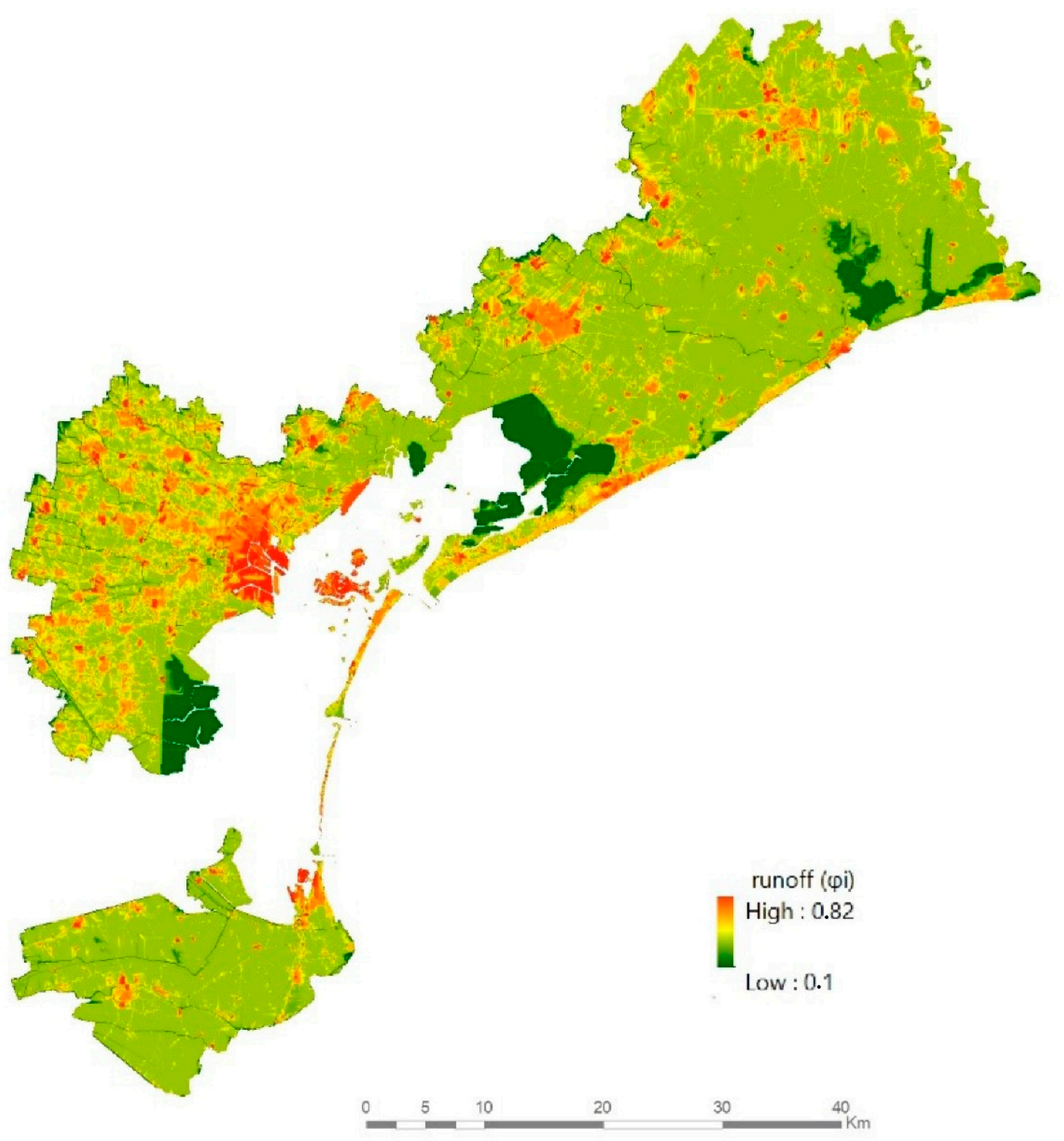

Figure 9. Metropolitan City of Venice: impacts on the hydraulic system for changes in land use in 2012 (Ccs 2012 plus). Run-off. 

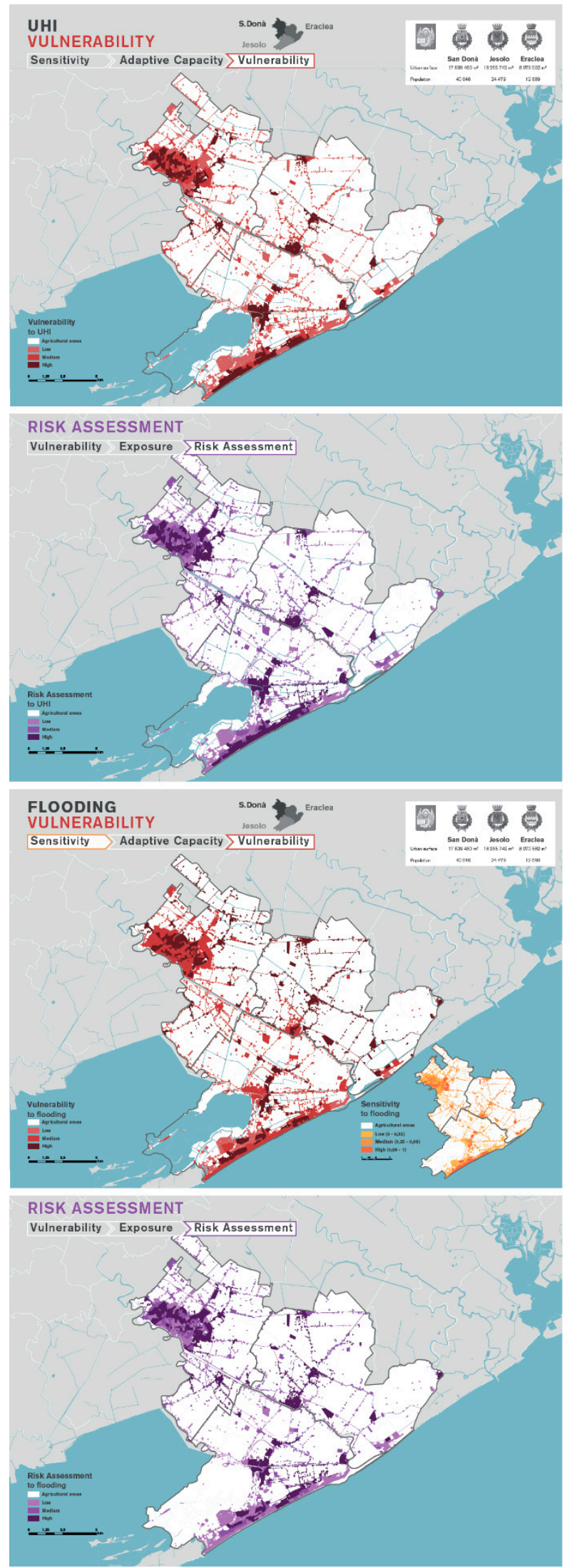

Figure 10. Vulnerability to heatwaves for the municipalities of San Donà di Piave, Jesolo and Eraclea; vulnerability to flooding and flooding for the municipalities of San Donà di Piave, Jesolo and Eraclea; risk assessment of heatwaves for the municipalities of San Donà di Piave, Jesolo and Eraclea; risk assessment of floods and floods for the municipalities of San Donà di Piave, Jesolo and Eraclea. Credits Maragno D., Università Iuav di Venezia. 
The choice to investigate the Municipality of San Donà di Piave (the agglomeration at the top left in the following images) derives from its particular exposure to flooding phenomena. This phenomenon will exacerbate with the intensification of the impacts of climatic changes. As we can see in the following images, the Municipality of San Donà di Piave is very vulnerable to heatwaves (Figure 10) and to flooding (Figure 10). According to the DST which will be later presented, in San Donà di Piave, the municipal area vulnerable to heat island is $3.94 \mathrm{~km}^{2}$ low, $12.1 \mathrm{~km}^{2}$ medium and $1.84 \mathrm{~km}^{2}$ high. The frequency level of flooding is $11.3 \mathrm{~km}^{2}$ medium and $2.24 \mathrm{~km}^{2}$ high.

This vulnerability, overlapped with the socio-economic exposure, shows that the risk assessment to these two hazards is very high (Figure 10).

The results made it possible to support the adaptation processes at the local level through the Territorial Information System (SIT) of the CMVe. The SIT allows one to observe the results both in graphical and tabular form. The decision support tool (DST) (Figure 11) developed for the pilot municipalities of the project (San Donà di Piave together with Jesolo and Eraclea), is a searchable site in which each municipality can investigate its territory to define its vulnerability and geolocalize characteristics. Municipalities, in this way, are accompanied in the strategic, political and practical decisions of which actions to implement, with what priority, but, above all, in which specific area of their territory. One or more municipalities of the three-San Donà di Piave, Eraclea and Jesolo—can be selected and information is automatically provided.

\subsection{Support for the Process Which Led to the Definition of Adaptation Goals and Strategies}

The goals-defined both thanks to a participatory process (Tables 1 and 2) and thanks to the DST mentioned in the previous chapter-were determined for the two chosen impacts: urban heat waves and urban floods.

For urban heat waves, the chosen goals are: (1.1) improve knowledge on all possible effects of extreme climatic events on the population and monitor their progress, (1.2) adapt health infrastructures and strengthen emergency management systems, (1.3) adequately disseminate information acquired and prepare effective awareness campaigns, (1.4) update urban planning models and techniques for urban green design, (1.5) increase knowledge of urban greenery to improve the management of heritage in situations of thermal stress, (1.6) raise awareness among citizens to the efficient management of private green heritage, (1.7) review of urban management tools, (1.8) update of urban green planning models and techniques, (1.9) increase in urban green heritage in favor of an enhancement of the supply of urban ecosystem services and (1.10) raise citizenship awareness of behavior suitable in situations of high thermal stress.

For urban flooding the chosen goals are: (2.1) increase knowledge of the territory, in particular of areas subject to possible flooding, (2.2) update urban planning and design models and techniques, (2.3) increase awareness of the population about areas vulnerable to flooding and (2.4) promote integrated coordination in hydraulic risk management between the various territorial policies.

\subsection{Definition of Nature-Based Solution and Mainstreaming of Specific Adaptation Measures in Existing Plans}

Subsequently, there has been the definition of nature-based solution measures and the mainstreaming of the following existing plans: PAT-Territorial Planning Plan; PI—Intervention Plan; Water Plan; Civil Protection Plan; River Contract; Master Adapt Project; Veneto Adapt Project; Works with the BIM Piave Consortium; Redevelopment works with the Eastern Veneto Reclamation Consortium; Initiatives with Veritas spa; Public spaces (urban redevelopment); Public green (urban redevelopment); Urban drainage (urban redevelopment); Initiatives of the Council of Basin "Lagoon of Venice"; Water Safety Plan; Agreement with Open Fiber spa. 


\section{THE TERRITORY INVOLVED}

Select the municipality

monesaly

\section{MORPHOLOGICAL}

KNOWLEDGE FRAMEWORK

Urbanized area (sq km)

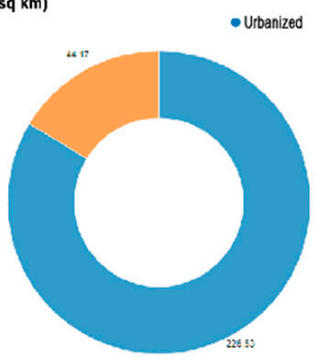

LOW

\section{VEGETATION}

In Urbanized area (sq km)

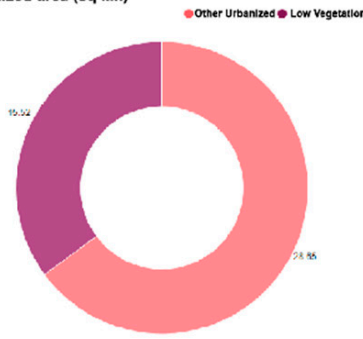

HIGH

\section{VEGETATION}

In Urbanized area (sq km)

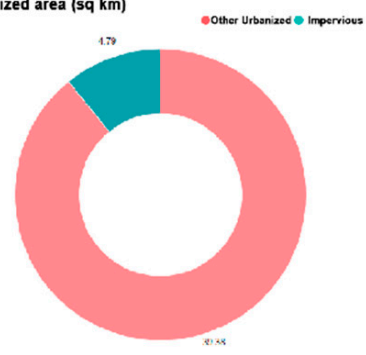

IMPERVIOUS

\section{SURFACE}

In Urbanized area (sq km)

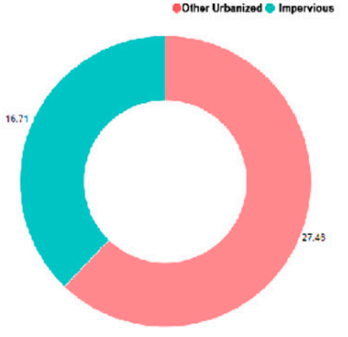

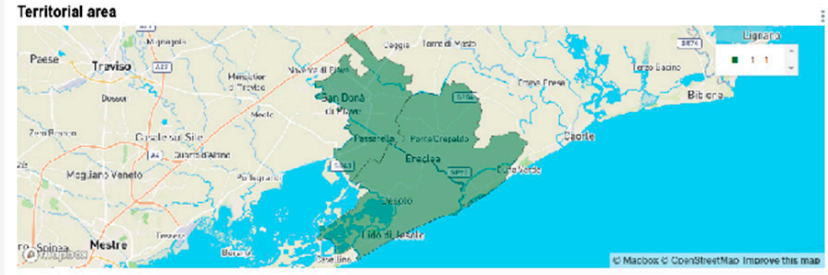

Urbanized area $(\%)$
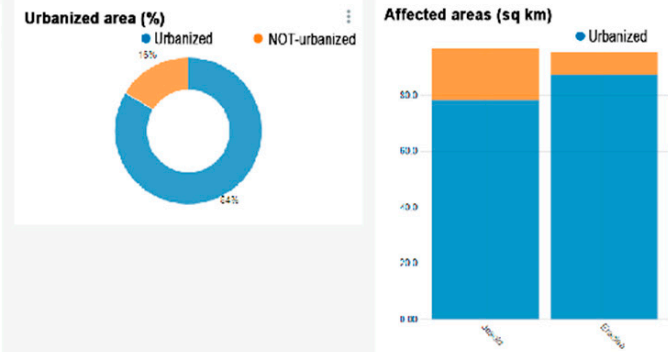

- NOT-urbanized

- NOT-urtanized

कै.
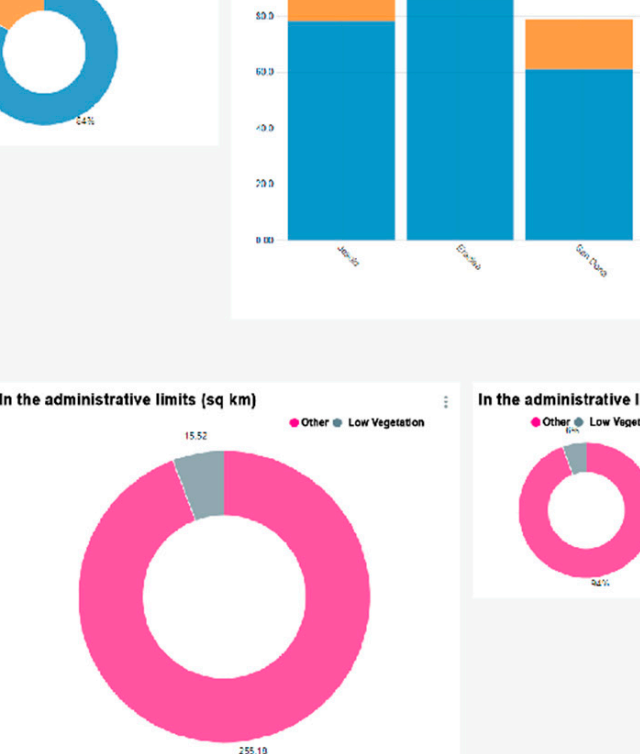

In the administrative limits - Other of Low Vesetation

In Urbanized area (\%)
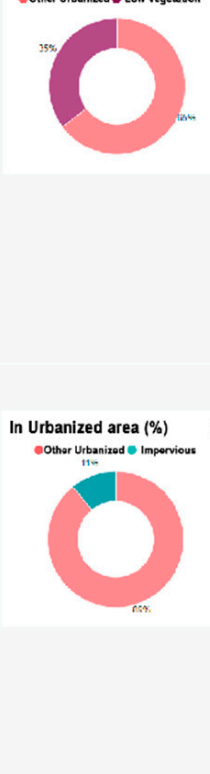

In the administrative limits (sq km)

In the administrative limits - Othere H High Vogetation
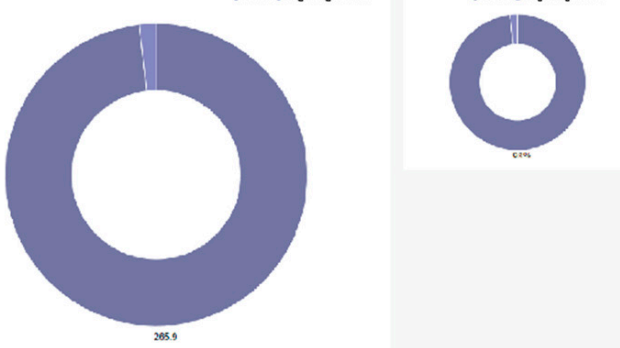

In Urbanized area (\%)

In the administrative limits $(\mathbf{s q ~} \mathbf{~ m m}$

In the administrative limits :

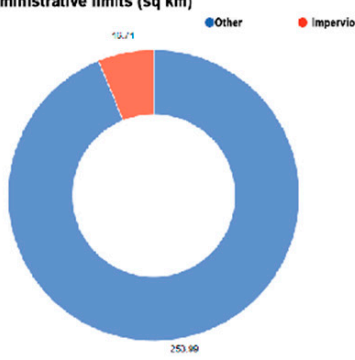

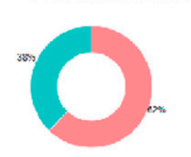

Figure 11. Cont. 


\section{BUILT AREA}
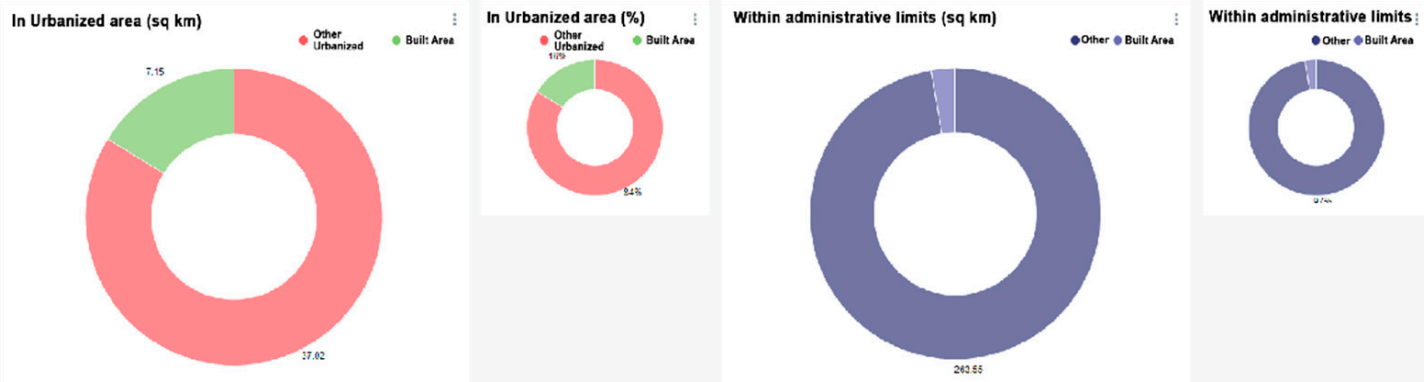

ATLAS OF THE SURFACES

Division of surfaces (sq km)

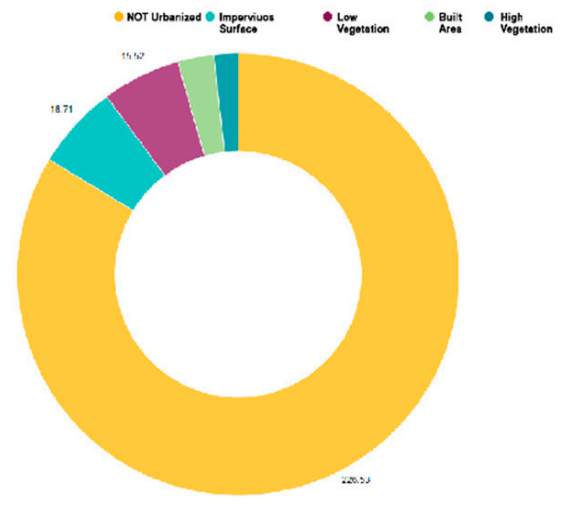

Division of surfaces (\%)

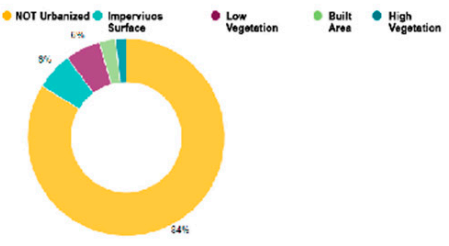

VULNERABILITY ANALYSIS

TO URBAN HEAT ISLAND
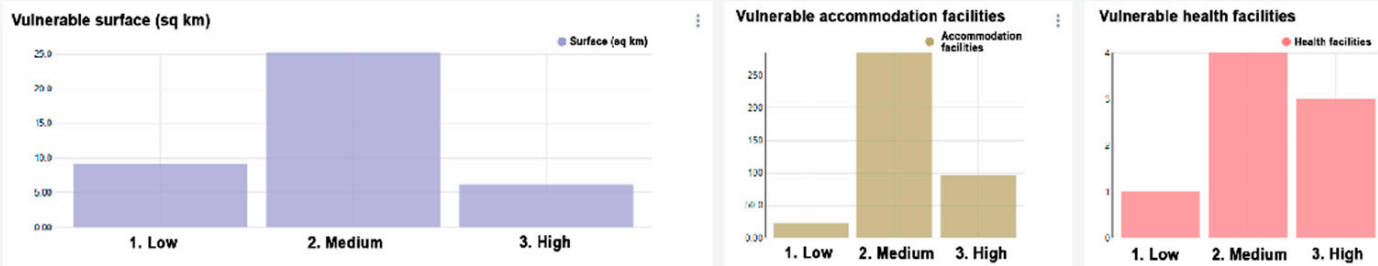

VULNERABILITY ANALYSIS

\section{TO URBAN FLOODING}

Flooding frequency level classification

Surface distribution with respect to the frequency of flooding
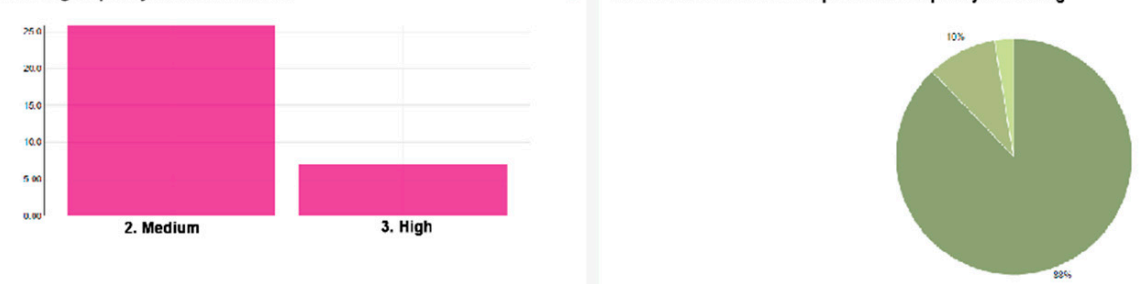

LLow M Medium $\mathrm{OH}$ igh

Figure 11. Decision Support Tool (DST): the entire territory, DST: methodological knowledge frameworks, DST: low vegetation, DST: high vegetation, DST: concreting area, DST: built-up area, reakdown of areas, DST: vulnerability analysis to the island of decline and DST: vulnerability analysis to flooding. 
Table 1. Report of the meetings and workshops.

\begin{tabular}{|c|c|c|c|}
\hline & First Meeting & Second Meeting & Third Meeting \\
\hline Date & 25 October 2018 & 31 October 2018 & 17 April 2019 \\
\hline Title & $\begin{array}{l}\text { Tools for governance and } \\
\text { mainstreaming adaptation at } \\
\text { local level|\#1/2 }\end{array}$ & $\begin{array}{l}\text { Tools for governance and } \\
\text { mainstreaming adaptation at } \\
\text { local level|\#2/2 }\end{array}$ & $\begin{array}{l}\text { Resilient metropolitan } \\
\text { municipalities: towards } \\
\text { adaptation to climate change }\end{array}$ \\
\hline Place & $\begin{array}{c}\text { Venice. Headquarter of } \\
\text { Metropolitan City of Venice }\end{array}$ & $\begin{array}{c}\text { Venice. Headquarter of } \\
\text { Metropolitan City of Venice, }\end{array}$ & $\begin{array}{c}\text { San Donà di Piave, Cultural } \\
\text { Centre "da Vinci" }\end{array}$ \\
\hline Contents & $\begin{array}{c}\text { Definition of the objectives } \\
\text { of adaptation to climate } \\
\text { change and the development } \\
\text { of synergies between entities } \\
\text { necessary for the } \\
\text { construction of an integrated } \\
\text { plan of intervention. }\end{array}$ & $\begin{array}{l}\text { Presentation of the } \\
\text { operational methods of } \\
\text { adaptation developed within } \\
\text { the project networks. } \\
\text { Confrontation on strategies } \\
\text { and tools used. }\end{array}$ & $\begin{array}{l}\text { Illustration of the Covenant of } \\
\text { Mayors in CMVE defined the } \\
\text { support to the municipalities in } \\
\text { the preparation of the PAESC } \\
\text { and preparation of the inventory } \\
\text { of the emissions and indications } \\
\text { on the guidelines for the } \\
\text { transition from PAES to PAESC, } \\
\text { explanation of adaptation and } \\
\text { analysis of the risks and } \\
\text { vulnerabilities of the Venice area, } \\
\text { good practices in comparison } \\
\text { and finally workshops with the } \\
\text { pilot area municipalities. }\end{array}$ \\
\hline
\end{tabular}

Table 2. Structure of the survey submitted to the three municipalities of San Donà di Piave, Jesolo and Eraclea.

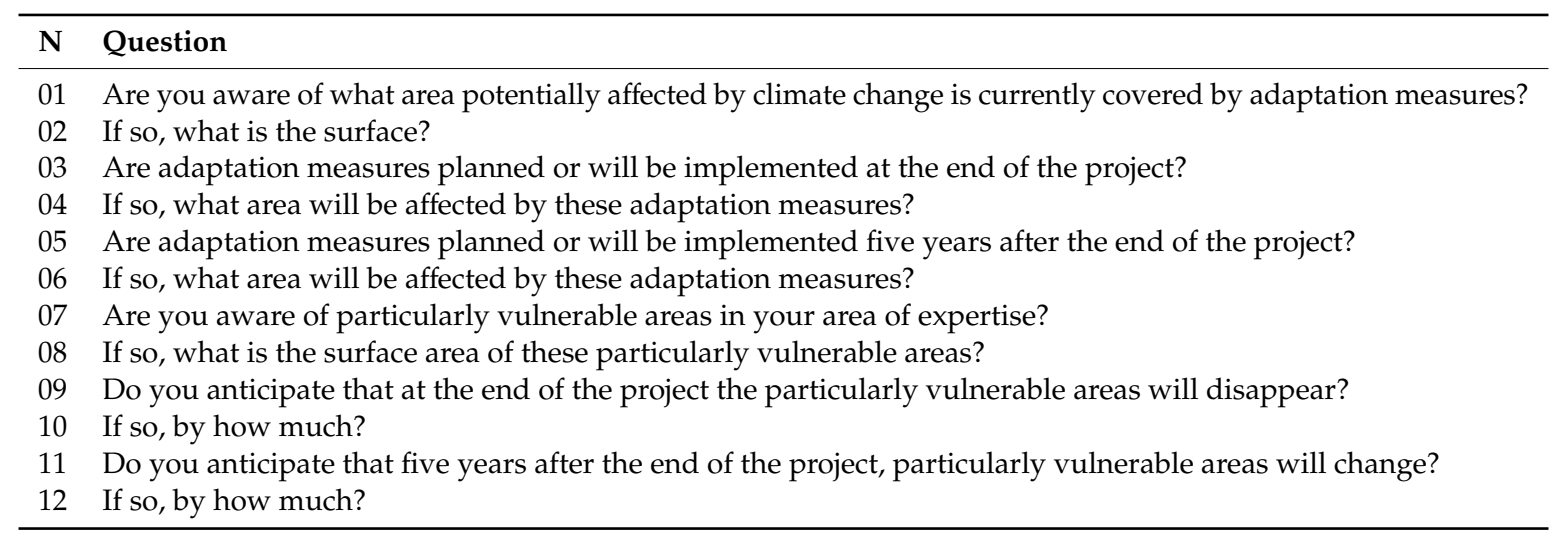

This matrix-defined by the project methodology contained in the "Policy Guidance for the definition of adaptation goals at the regional and local level and the related governance" (Action C1) [36] - was subsequently used with appropriate modifications also in the SECAP, creating its strategic vision. The matrix was built specifically for the area of San Donà di Piave with different public meetings (Table 1) [31]. This vision gave life to the goals of the SECAP of the Municipality of San Donà di Piave (Table 3), at a later time, to the specific NBS actions.

The Municipality of San Donà di Piave was already active and sensitive to the issues of environmental sustainability and in the fight against climatic changes. With the DST and the operational methodology indicated by Master Adapt and applied to the municipality, the San Donà di Piave municipality harnessed its efforts and its technical and economic energies towards site-specific territorial adaptation interventions and NBSs.

The unanimous and shared definition of the aforementioned goals, vision and strategies gave life to the consequent actions that will now be presented. Actions, in the SECAP, are not merely a set of commitments but represent a global vision of territorial planning (Figure 12). 
Table 3. Goals of LIFE Master Adapt, Metropolitan City of Venice compared to the goals of the Action Plan for Sustainable Energy and Climate (SECAP) of San Donà di Piave.

\begin{tabular}{lc}
\hline $\begin{array}{c}\text { Goals of LIFE Master Adapt, Metropolitan } \\
\text { City of Venice }\end{array}$ & Goals of the SECAP, San Donà di Piave \\
\hline & "Adaptation" into local and supra-municipal planning \\
\cline { 2 - 2 } $\begin{array}{c}\text { Updating urban planning and design models } \\
\text { and techniques }\end{array}$ & The Urban Drainage; \\
\cline { 2 - 2 } $\begin{array}{c}\text { Increasing knowledge of the territory, in } \\
\text { particular of areas subject to possible flooding }\end{array}$ & The cultural enhancement of the land reclamation \\
\hline $\begin{array}{c}\text { Raising public awareness of areas vulnerable } \\
\text { to flooding }\end{array}$ & The exploitation of good practices in agriculture \\
\hline $\begin{array}{c}\text { Promotion of integrated coordination in the } \\
\text { management of hydraulic risk between the } \\
\text { different territorial policies. }\end{array}$ & Active participation in supra-municipal projects for the SEAP \\
\cline { 2 - 2 }
\end{tabular}

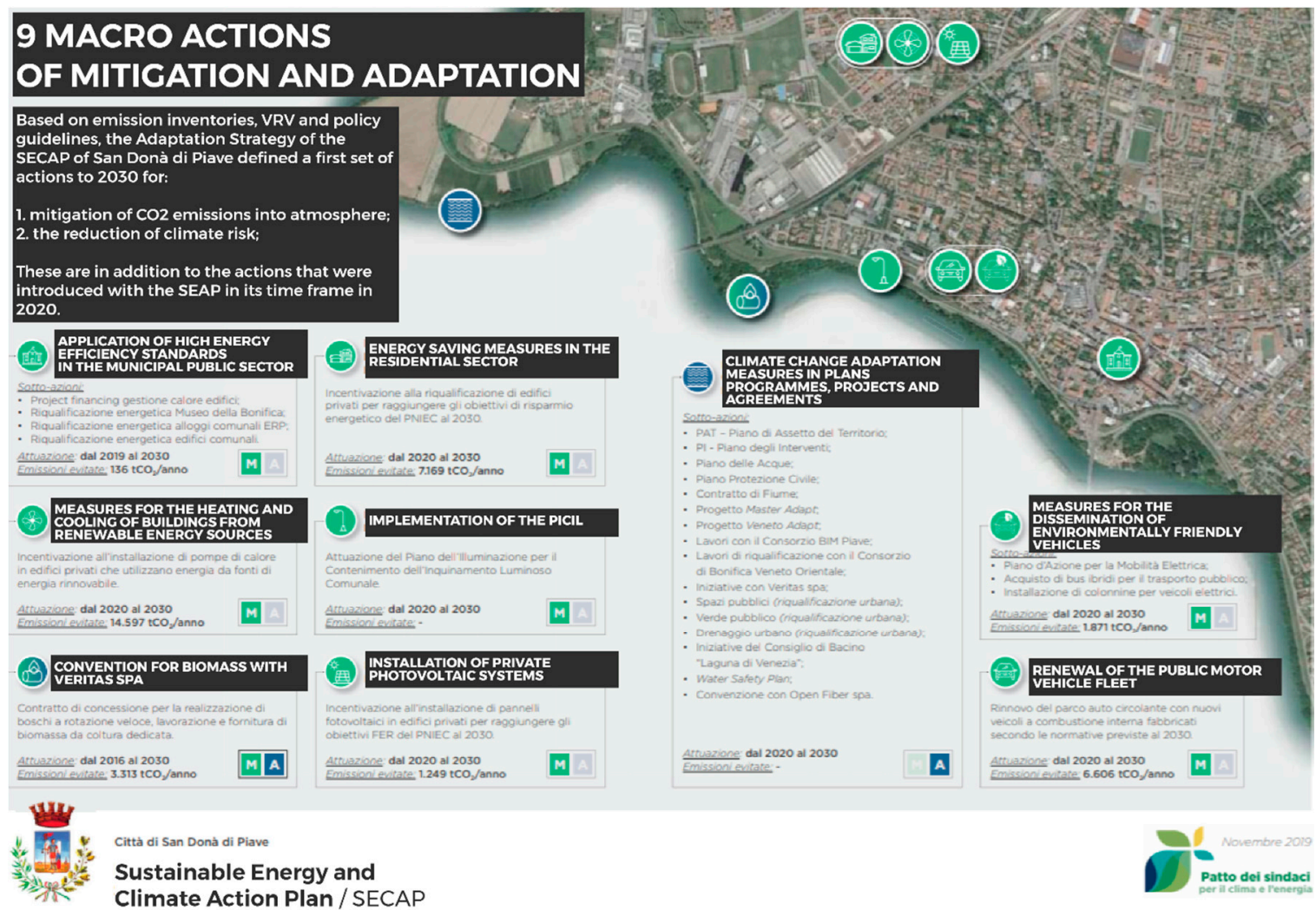

Figure 12. Masterplan of the mitigation (green) and adaptation (blue) actions into the SECAP of San Donà di Piave. The adaptation actions are here comprehensive of the Nature-Based Solutions, especially alongside the Piave river. Source: SECAP of San Donà di Piave.

The SECAP contains a prevalence of measures that refer to Nature-Based Solutions (Table 4); this choice to favor the NBS occurred not only for a political choice but above all for the path of scientific analysis which the municipality has decided to use. The definition of the actions responds to concrete and locally specific needs-if mitigation is aimed at a broad context, adaptation must necessarily refer to the needs localized in the territory in which climate change produce effects. 
Table 4. The actions of the SECAP of San Donà di Piave.

\begin{tabular}{|c|c|c|}
\hline Proposed Action & Description & Tipology \\
\hline $\begin{array}{l}\text { Integration of adaptation } \\
\text { measures climate change in plans, } \\
\text { programs, projects and agreements }\end{array}$ & $\begin{array}{l}\text { Development of integrated planning and programming } \\
\text { tools, consistent with the SEAP's climate change } \\
\text { adaptation strategies and objectives, aimed at designing } \\
\text { effective adaptation measures. }\end{array}$ & Policy \\
\hline PAT_Spatial Planning Plan & $\begin{array}{l}\text { Integrate objectives and measures to adapt to climate } \\
\text { change into the municipality's strategic spatial planning } \\
\text { instrument. }\end{array}$ & Policy \\
\hline PI-Plan of Interventions & $\begin{array}{l}\text { Integrate climate change adaptation measures into the } \\
\text { Land Planning Implementation Instrument. }\end{array}$ & Policy \\
\hline Plan of Water & $\begin{array}{l}\text { Integrating climate change adaptation measures into the } \\
\text { water management tool of the smaller municipal } \\
\text { network. }\end{array}$ & Policy \\
\hline Civil Protection Plan & $\begin{array}{l}\text { Develop the Civil Protection Plan with specific themes } \\
\text { and measures for the management of risks arising from } \\
\text { climate change to increase the security and resilience of } \\
\text { the community. }\end{array}$ & Policy \\
\hline River contract & $\begin{array}{l}\text { Address, in an integrated and participatory way, } \\
\text { situations of critical consequences of climate change and } \\
\text { soil sealing levels }\end{array}$ & Policy \\
\hline $\begin{array}{l}\text { Work with the BIM Piave } \\
\text { Consortium } \# 1\end{array}$ & $\begin{array}{l}\text { Increase the resilience of the territory to climate change } \\
\text { by addressing, in an integrated way, critical situations } \\
\text { related to the river Piave. } \\
\text { - Management of Piave banks } \\
\text { - Movable and fixed piers along the Piave Redevelopment } \\
\text { works with the Consortium of Bonifica Veneto Orientale: } \\
\text { - Channel adjustment } \\
\text { - Renovation in pipeline and cycle path "from train to sea" } \\
\text { - Interventions following exceptional weather events } \\
\text { - Strengthening the urban network }\end{array}$ & Intervention \\
\hline $\begin{array}{l}\text { Work with the BIM Piave } \\
\text { Consortium \#2 }\end{array}$ & $\begin{array}{l}\text { Increase the resilience of the territory to climate change } \\
\text { through the active collaboration of the authorities of land } \\
\text { management, thanks to initiatives and interventions } \\
\text { connected to the network and the works of the } \\
\text { Consortium of Reclamation Eastern Veneto. } \\
\text { - Management of Piave banks } \\
\text { - Movable and fixed piers along the Piave } \\
\text { Redevelopment works with the Consortium of Bonifica } \\
\text { Veneto Orientale: } \\
\text { - Channel adjustment } \\
\text { - Renovation in pipeline and cycle path "from train to sea" } \\
\text { - Interventions following exceptional weather events } \\
\text { - Strengthening the urban network }\end{array}$ & Intervention \\
\hline
\end{tabular}

\begin{tabular}{cll}
\hline $\begin{array}{c}\text { Redevelopment work with Veritas } \\
\text { spa for sewage treatment plants } \\
\begin{array}{c}\text { Urban redevelopment-public } \\
\text { spaces: Porta Nuova }\end{array}\end{array}$ & $\begin{array}{l}\text { Collaboration with the concessionary company Veritas } \\
\text { spa for initiatives aimed at increasing the resilience to } \\
\text { climate change of environmental services in the territory }\end{array}$ & Intervention \\
\hline $\begin{array}{c}\text { Redevelopment work with Veritas } \\
\text { spa for sewage treatment plants } \\
\text { Urban redevelopment-public } \\
\text { spaces: Porta Nuova }\end{array}$ & $\begin{array}{l}\text { Increasing climate resilience through urban regeneration } \\
\text { projects. }\end{array}$ & Intervention \\
\hline $\begin{array}{c}\text { Urban } \\
\text { regeneration-Interventions on } \\
\text { public green areas }\end{array}$ & $\begin{array}{l}\text { Increasing resilience to climate change through urban } \\
\text { public green regeneration projects: increasing the surface } \\
\text { area and improving the functionality of green urban } \\
\text { infrastructure. }\end{array}$ & Intervention \\
\hline
\end{tabular}


Table 4. Cont.

\begin{tabular}{|c|c|c|}
\hline Proposed Action & Description & Tipology \\
\hline $\begin{array}{c}\text { Urban regeneration-Urban } \\
\text { drainage: } \\
\text { - Pilot project The Rain } \\
\text { Garden-Primary School Marco } \\
\text { Polo Calvecchia } \\
\text { - Rain garden }\end{array}$ & $\begin{array}{l}\text { Drainage and management of rainwater collected on } \\
\text { large waterproofed surfaces such as roofs, squares and } \\
\text { roads are structural actions essential for increasing the } \\
\text { resilience of urban areas in conjunction with weather } \\
\text { events of particularly intense rain. The measures } \\
\text { collected under this action relate to projects } \\
\text { implementing the sustainable urban drainage of } \\
\text { rainwater, capable of combating flooding, waterproofing } \\
\text { of land and improving the collection and use of white } \\
\text { water and the efficiency of the sewerage system }\end{array}$ & Intervention \\
\hline $\begin{array}{l}\text { Initiatives of the Council of Basin } \\
\text { "Laguna di Venezia":-New Plan } \\
\text { of the Integrated Water Service }\end{array}$ & $\begin{array}{l}\text { Increasing the resilience of the site to climate change } \\
\text { through the active collaboration of land management } \\
\text { authorities. Collaboration with the Authority of Within } \\
\text { of the Basin "Lagoon of Venice" to increase the resilience } \\
\text { to the climate changes of the integrated water services of } \\
\text { the territory. Consider climate change risk factors in the } \\
\text { assessment and management of drinking water risk } \\
\text { across the water supply chain to contain risks to human } \\
\text { health. }\end{array}$ & Intervention \\
\hline Water Safety Plan & $\begin{array}{l}\text { Increasing the resilience of the site to climate change } \\
\text { through the active collaboration of land management } \\
\text { authorities. Collaboration with the Authority of Within } \\
\text { of the Basin "Lagoon of Venice" to increase the resilience } \\
\text { to the climate changes of the integrated water services of } \\
\text { the territory. Consider climate change risk factors in the } \\
\text { assessment and management of drinking water risk } \\
\text { across the water supply chain to contain risks to human } \\
\text { health. }\end{array}$ & Policy \\
\hline $\begin{array}{l}\text { Concession contract for the } \\
\text { construction of fast rotation } \\
\text { forests, processing and supply of } \\
\text { dedicated crop biomass. }\end{array}$ & $\begin{array}{l}\text { Use of fuels from renewable energy sources to reduce net } \\
\mathrm{CO}_{2} \text { emissions to the atmosphere. }\end{array}$ & Policy \\
\hline
\end{tabular}

Adherence to SEAPs has not always given concrete results and perpetuated the administration's commitment to the environmental challenge: if the signatory municipalities, in Italy, were 4736, the consequent Action Plans were 3304 (69.76\%) and the monitored results were only 1022 (just 21.58\%) [37]. The SECAP of San Donà di Piave, also to obviate this risk and to be highly operational and concrete, defined for each action the actors who will deal, in various capacities, with its implementation.

As described in the SECAP of San Donà di Piave, "by joining the Covenant of Mayors, the Municipal Administration undertakes a path that, to be managed effectively, requires a specific organization of offices, the allocation of adequate budgetary resources and support of particular external structures". It is necessary to organize, within the administration, "an organizational structure with the specific task of guiding, coordinating and monitoring the actions of the SECAP [...] (Figure 13). The organizational and coordination structure that the Municipality wanted to set up for the implementation of the Action Plan provides for the bodies and subjects listed in the following scheme" (Figure 14) [38]. 


\section{ED - BUILDINGS, PLANTS / EQUIPMENT}

\begin{tabular}{|c|c|c|c|c|c|c|c|c|c|c|c|}
\hline \multicolumn{12}{|l|}{$\begin{array}{l}\text { ACTION } 3 \\
\text { ED2.2 - S }\end{array}$} \\
\hline \multicolumn{12}{|c|}{ Application of high standards of energy efficiency in the municipal public sector. } \\
\hline GOAL & \multicolumn{11}{|c|}{$\begin{array}{l}\text { Apply the highest standards of energy efficiency in the construction of new public } \\
\text { buildings and major renovations in order to provide citizens with examples of low- } \\
\text { consumption buildings. }\end{array}$} \\
\hline DESCRIPTION & \multicolumn{11}{|c|}{$\begin{array}{l}\text { This action aims to extend the action of the SEAP ED. } 2 \text { scheduled until } 2020 \text {, to } 2030 \text {, } \\
\text { aiming to reduce consumption in the municipal public sector by } 10 \% \text { compared to the } \\
2017 \text { IME. } \\
\text { Action ED. } 2 \text { of the SEAP has the following objectives: } \\
\text { 1. The sustainable development of public buildings; } \\
\text { 2. The promotion of energy saving towards citizens; }\end{array}$} \\
\hline \multicolumn{12}{|l|}{ IMPLEMENTING } \\
\hline $\begin{array}{r}\text { POLITICAL } \\
\text { INSTRUMENT }\end{array}$ & \multicolumn{11}{|l|}{ National } \\
\hline $\begin{array}{r}\text { ORIGIN OF } \\
\text { THE ACTION }\end{array}$ & \multicolumn{11}{|l|}{ Municipal } \\
\hline $\begin{array}{r}\text { RESPONSIBLE } \\
\text { BODY }\end{array}$ & \multicolumn{11}{|c|}{ Sector 5 - Sector 4} \\
\hline STAKEHOLDER & \multicolumn{11}{|c|}{ Citizens, Municipal Administration. } \\
\hline ESTIMATED & \\
\hline costs & \multicolumn{11}{|l|}{ n.d. } \\
\hline PERIOD OF & 20192020 & 2021 & 2022 & 2023 & 2024 & 2025 & 2026 & 2027 & 2028 & 2029 & 2030 \\
\hline \multicolumn{12}{|l|}{ IMPLEMENTATION } \\
\hline \multirow{2}{*}{$\begin{array}{l}\text { EXPECTED } \\
\text { RESULTS }\end{array}$} & \multicolumn{3}{|c|}{$\begin{array}{c}\text { EXPECTED } \\
\text { ENERGY SAVINGS }\end{array}$} & \multicolumn{4}{|c|}{$\begin{array}{l}\text { PRODUCTION } \\
\text { FROM RENEWABLE } \\
\text { SOURCES }\end{array}$} & \multicolumn{4}{|c|}{$\begin{array}{l}\text { AVOIDED CO2 } \\
\text { EMISSIONS }\end{array}$} \\
\hline & \multicolumn{3}{|c|}{$\begin{array}{l}84 \mathrm{MWh}_{\text {elettr/year }} \\
466 \mathrm{MWh}_{\text {term }} / \text { year }\end{array}$} & \multicolumn{4}{|c|}{$0 \mathrm{MWh}$} & \multicolumn{4}{|c|}{$136 \mathrm{t} \mathrm{CO}_{2} /$ year } \\
\hline MONITORING & nergy con & & & & & & & & & & \\
\hline
\end{tabular}

Figure 13. Example of action from the SECAP of San Donà di Piave. The action contains title, goal, description, responsible for the action, stakeholders involved, cost, period of implementation and expected results. 


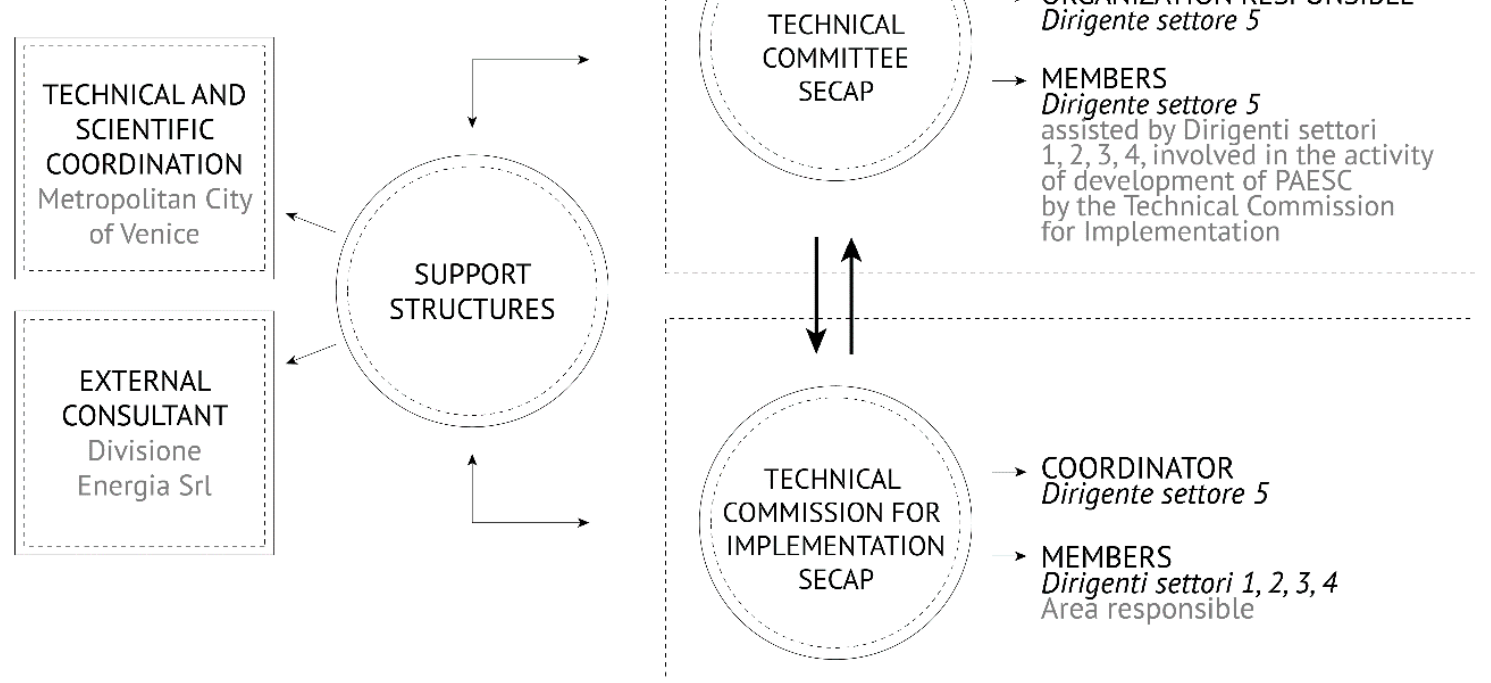

Figure 14. Organizational structure with the specific task of guiding, coordinating and monitoring the actions of the SECAP in San Donà di Piave.

\section{Discussion}

Adaptation processes have the primary need to have an in-depth knowledge of the territories to cope with specific impacts deriving from climate change. Studying the area and making it known more deeply to policymakers and technical offices is the first step to know how to decide with awareness on which actions to focus more on.

Over the past 20 years, the need to address climate change dynamics in cities has been recognized at institutional, academic and operational levels in urban management practices [39-42]. Mitigation and adaptation approaches are increasingly recognized and evaluated in territorial governance $[43,44]$. The latter, adaptation, unlike mitigation, should be based on the geomorphological and climatic specificities of the place, as well as on the practices already initiated by local communities [45] which is why the cognitive phase is critical. Concerning settlements, it is strategically important to recognize the values of vulnerability [46] thanks to an analysis of morphological structures, their physical-functional components, their eco-characteristic systemic and, more generally, dynamic equilibrium conditions [47]. This is why it is necessary to increase the levels of knowledge available by making spatial information interoperable [48].

The aim of climate-proof planning is, therefore, to redirect the urban system towards a reduction in climate-changing emissions (mitigation) and at the same time to modify urban systems to make them more resilient to possible climate impacts (adaptation).

Concerning environmental and natural conditions, the urban, infrastructural and settlement system and historical-cultural and socio-economic aspects, the importance of building a knowledge framework providing a comprehensive description of the territory and its evolutionary process is clear. Effective adaptation measures are, in fact, those that can compensate vulnerabilities with the addition of corrective functions, designed to reduce the specific impacts of the territory.

The result obtained from the process on the Municipality of San Donà di Piave, together with the validity of the NBS proposals, were defined concerning the needs dictated by the territorial exposures that emerged with the analysis. The results emerged thanks to the unity of the three steps in a common perspective. The problems discussed in the introduction phase were resolved precisely by being aware that only a linear and well-defined process ensures success. 
This clear and comprehensive process defined by LIFE Master Adapt consists of:

- territorial analysis (risk assessment);

- selection of goals linked with European and national strategies;

- definition of nature-based solutions starting from what is already implemented by different actors;

- creation of a single table to bring together actors who are usually used to work separately.

The methodology used in the Municipality of San Donà di Piave—-thanks to the LIFE Master Adapt project-allowed it to:

- approach territorial planning by defining goals and implementing actions thanks to a very consistent analysis phase;

- exploit the matrix of adaptation options also for defining the SECAP strategy, creating its strategic vision.

Therefore, the transversality of the application of nature-based solutions was achieved both between existing plans, projects and mandatory programs and with what has already been proposed by the territory (local authorities and investee companies). The mainstreaming of adaptation and NBS actions in the Municipality of San Donà di Piave is carried out in practice with the constant action and choices of the administrators and technical departments and with the support of stakeholders.

The work carried out thanks to the LIFE Master Adapt project in the Municipality of San Donà di Piave is relevant. Indeed, it has contributed to the definition of a SECAP. The process started from a precise analysis of the territory and then proposed solutions and actions-policy, organizational, physical - that act specifically on the areas that are most affected by impacts of climate change. The SECAP mainstreams NBS in various plans and programs. This is a necessary process to make the territory more climate-proof since adaptation needs answers to be as specific as possible.

The DST and the training sessions for technicians and policymakers made it possible to modify the practice and processes of the public administration, managing to apply the mainstreaming of climate change adaptation actions. Thanks to this innovation, six plans and 10 programs have been contaminated, giving concreteness to the goals set by the City of San Donà di Piave.

Moreover, the Metropolitan City of Venice considered this experimentation carried out on the three municipalities very innovative and decided to translate the DST into a WEB-GIS (World Wide Web-Geographic Information System) available to all 44 municipalities of the CMVe.

The role of the Metropolitan City of Venice was fundamental in:

- $\quad$ supporting municipalities in the mainstreaming processes;

- $\quad$ supporting the definition of a free and shared metropolitan knowledge framework (DST);

- training municipal technicians and accompanying the definition of the matrix vision/goals/action that has allowed shared reasoning on a large scale.

As reported in the different territorial reports of the pilot areas of LIFE Master Adapt [31], one of the main problems of adaptation policies is that they are entrusted to the voluntary aspect. Indeed, depending on the political alternation and decisionmakers' sensitivity, public bodies may or may not choose to invest time, resources and personnel in making their territory more resilient to climate change.

The creation of a single table to bring together actors who are usually used to working separately—as it was carried out in San Donà di Piave—can help to resolve this criticality, but it does not ensure the stability of the policies. An additional effort would be needed to make adaptation a stable process within public administrations.

This could happen perhaps creating permanent offices that deal with the issue within the administrations. There is no doubt that an important role is played by the political body which will have to promote and develop the process of mainstreaming adaptation actions, through a technical committee and specific working groups and involve stakeholders to mobilize civil society around the adaptation plan. 


\section{Conclusions}

The risk that adaptation or mitigation initiatives are not successful is often high. This can happen because of a change in the political direction of the city, because of a poor ability to carry out projects, or because of a lack of coordination in the initiatives between stakeholders.

The case of San Donà di Piave shows how the modification of planning tools and administrative practices can happen with a clear, linear and collaborative path between stakeholders together with a strong territorial analysis

In San Donà di Piave, NBSs and adaptation actions permeated plans, programs and projects relating to the municipal territory with NBS and actions for adaptation to climate change. Otherwise, these strategic interventions-green, grey, or blue-that favor the storage of the water resource, exploitation in the non-emergency phase and controlled flow during extreme events as well as adaptation actions, should be translated into mandatory plans for territorial planning.

Moreover, the case of San Donà di Piave shows how it is possible to direct the actions and economic resources of a public administration with a clear strategic vision. This allows to address and secure the territory with a global and unified vision. The support of the Iuav University of Venice has therefore made it possible to modify the territorial planning of the municipality mainstreaming adaptation actions to climate change and NBS with a solid scientific basis. It is desirable and necessary to replicate the process in other municipalities of the Metropolitan City of Venice toward a climate-proof metropolitan city.

NBS and climate change adaptation processes can therefore lead to concrete and successful results on the ground if they are integrated into well-defined processes and coordinated between agencies and stakeholders. The NBSs that have been proposed in San Donà di Piave are inserted in a virtuous process that sees a strong collaboration between entities. However, this was achieved through a strong commitment on the part of technical departments and political decisionmakers.

The future effort, at different levels of decisionmaking, legislative and regulatory, must necessarily engage in a change of pace towards greater cogency in the use of NBS as actions to adapt to climate change.

A further critical issue that needs to be stressed is the need to provide data, information and knowledge on aspects closely linked to the evolution of the climate and not limited to environmental protection and sustainable development. To do this, it is necessary to insist on providing the necessary knowledge to technical offices, political decisionmakers and the public, to give due importance to the climate impacts which, otherwise, could be underestimated. The project noted that an important coordinating role on this issue could be provided by large area bodies such as metropolitan cities or aggregations of municipalities.

Author Contributions: F.M. (Filippo Magni), G.L., G.C. have worked on the Conceptualization of the article; F.M. (Filippo Magni) and G.L. have designed the Methodology applied to the process; G.C. has supported all the works related to Softwares management, Data Curation, and Formal Analysis; G.L. and F.M. (Filippo Magni) have managed the Validation process of the results, F.M. (Francesco Musco) has supervised the Investigation process; G.L., G.C. and F.M. (Filippo Magni) have Prepared Writing-Original Draft; All authors have Writed-Reviewed \& Edit the paper; G.C. has Prepared the Visualization of the information; F.M. (Filippo Magni) and F.M. (Francesco Musco) have Supervisioned the entire process of the research; F.M. (Filippo Magni) and F.M. (Francesco Musco) have the scientific responsibility of the Project Administration; F.M. (Francesco Musco) has followed the process for Funding Acquisition. All authors have read and agreed to the published version of the manuscript.

Funding: EPiC Earth and Polis Research Centre, LIFE Master Adapt.

Conflicts of Interest: The authors declare no conflict of interest.

\section{References}

1. AAVV. Atlante della Laguna. Venezia tra Terra e Mare; Marsilio: Venice, Italy, 2006.

2. Sistema Nazionale per la Protezione dell'Ambiente (SNPA). Rapporto "Consumo di Suolo, Dinamiche Territoriali e Servizi Ecosistemici"; SNPA: Rome, Italy, 2019. 
3. Ministero dell'Ambiente e della Tutela del Territorio e del Mare (MATTM). Piano Nazionale di Adattamento ai Cambiamenti Climatici PNACC; MATTM: Roma, Italy, 2016.

4. Antonioli, F. Sea-level rise and potential drowning of the Italian coastal plains: Flooding risk scenarios for 2100. J. Maps 2017, 13, 961-967. [CrossRef]

5. Indovina, F. La Città Diffusa; Istituto Universitario di Architettura di Venezia, Dipartimento di Analisi Economica E Sociale del Territorio: Venice, Italy, 1990.

6. EU Climate Change Adaptation Strategy. Available online: www.eur-lex.europa.eu/legal-content/IT/TXT/ PDF/?uri=CELEX:52013DC0216\&from=EN (accessed on 18 October 2020).

7. UNFCC - United Nations Framework Convention on Climate Change. The Paris Agreement. Available online: www.unfccc.int/process-and-meetings/the-paris-agreement/the-paris-agreement (accessed on 28 October 2020).

8. CMCC, SNACC-Elements to Develop a National Adaptation Strategy to Climate Change. Available online: www.cmcc.it/projects/snac-elements-to-develop-a-national-adaptation-strategy-to-climate-change (accessed on 11 June 2020).

9. The European Green Deal. Available online: www.eur-lex.europa.eu/legal-content/EN/TXT/?qid= 1588580774040\&uri=CELEX:52019DC0640 (accessed on 10 November 2020).

10. European Climate Law. Available online: https://ec.europa.eu/clima/policies/eu-climate-action/law_en (accessed on 10 November 2020).

11. The European Green Deal Investment Plan and Just Transition Mechanism. Available online: https: //ec.europa.eu/commission/presscorner/detail/en/qanda_20_24 (accessed on 10 November 2020).

12. Ministero dell'Ambiente e della Tutela del Territorio e del Mare (MATTM). SNACC—Strategia Nazionale di Adattamento ai Cambiamenti Climatici; MATTM: Rome, Italy, 2014.

13. Ministero dell'Ambiente e della Tutela del Territorio e del Mare (MATTM). PNACC—Piano Nazionale di Adattamento ai Cambiamenti Climatici; MATTM: Rome, Italy, 2017.

14. Coronato, M. The Sustainability Dimensions: A Territorialized Approach to Sustainable Development. 2020. Glob. J. Hum.-Soc. Sci. 2020, 20, 23-32. [CrossRef]

15. Reckien, D.; Salvia, M.; Heidrich, O.; Church, J.M.; Pietrapertosa, F.; de Gregorio-Hurtado, S.; d'Alonzo, V.; Foley, A.; Simoes, S.G.; Lorencová, E.K.; et al. How are cities planning to respond to climate change? Assessment of local climate plans from 885 cities in the EU-28. J. Clean. Prod. 2018, 191, 207-219. [CrossRef]

16. Bulkeley, H.; Kern, K. Local Government and the Governing of Climate Change in Germany and the UK. Urban Studies 2003, 43, 12. [CrossRef]

17. Hunt, A.; Watkiss, P. Climate change impacts and adaptation in cities: A review of the literature. Clim. Chang. 2011, 104, 13-49. [CrossRef]

18. Kousky, C.; Schneider, S.H. Global Climate Policy: Will Cities Lead the Way? Clim. Policy 2003, 145, 1-14. [CrossRef]

19. Walker, R.V.; Beck, M.B.; Hall, J.W.; Dawson, R.J.; Heidrich, O. The energy-water-food nexus: Strategic analysis of technologies for transforming the urban metabolism April 2014. J. Environ. Manag. 2017, 141, 104-115. [CrossRef] [PubMed]

20. IPCC. AR5 Synthesis Report: Climate Change 2014; IPCC: Geneva, Switzerland, 2014.

21. Wamsler, C.; Brink, E.; Rivera, C. Planning for climate change in urban areas: From theory to practice. J. Clean. Prod. 2013, 50, 68-81. [CrossRef]

22. EU Covenant of Mayors, Plans \& Actions. Available online: www.eumayors.eu/plans-and-actions/actionplans.html (accessed on 9 June 2020).

23. Businaro, G. Beni Comuni Urbani Per Una Nuova Alleanza Tra Istituzioni E Cittadini. Master's Thesis, Università Iuav di Venezia, Venice, Italy, 2019.

24. IUCN. Available online: www.iucn.org (accessed on 7 October 2020).

25. Maes, J.; Jacobs, S. Nature-Based Solutions for Europe's Sustainable Development. Conserv. Lett. 2017, 10, 121-124. [CrossRef]

26. World Bank. Nature-Based Solutions for Disaster Risk Management; World Bank: Washington, WA, USA, 2018.

27. Mittermeier, R.A.; Totten, M.; Pennypacker, L.L.; Boltz, F.; Mittermeier, C.G.; Midgley, G.; Rodriguez, C.M.; Prickett, G.; Gascon, C.; Seligmann, P.A.; et al. A Climate for Life: Meeting the Global Challenge; CEMEX Conservation Book Series; CEMEX: Washington, WA, USA, 2008. 
28. Cohen-Shacham, E.; Walters, G.; Janzen, C.; Maginnis, S. Nature-Based Solutions to Address Global Societal Challenges; IUCN: Gland, Switzerland, 2016. [CrossRef]

29. United Nations Global Compact (UNGC). UN Global Compact Progress Report 2019; UNGC: New York, NY, USA, 2019.

30. LIFE Master Adapt. Available online: https://masteradapt.eu/ (accessed on 17 April 2020).

31. LIFE Master Adapt. Case Study Report (Action C3); LIFE Master Adapt: Cagliari, Italy, 2020.

32. LIFE Master Adapt. Guidelines for Mainstreaming in Groups of Municipalities (Action C3); LIFE Master Adapt: Cagliari, Italy, 2020.

33. LIFE Master Adapt. Guidelines, Principles and Standardized Procedures for Climate Analysis and Vulnerability Assessment at the Regional and Local Level within (Action A1); LIFE Master Adapt: Cagliari, Italy, 2020.

34. LIFE Master Adapt. Climate Analysis and Vulnerability Assessment: Results for the Pilot Region and in the Target Areas of Action C3 (Action A1); LIFE Master Adapt: Cagliari, Italy, 2020.

35. LIFE Master Adapt. Smart Tools: Interactive Map and Common DSS (Action C3.2); LIFE Master Adapt: Cagliari, Italy, 2020.

36. LIFE Master Adapt. Policy Guidance for the Definition of Adaptation Objectives at the Regional and Local Level and the Related Governance (Action C1); LIFE Master Adapt: Cagliari, Italy, 2020.

37. Patto dei Sindaci. Available online: www.pattodeisindaci.eu/ (accessed on 21 June 2020).

38. Comune di San Donà di Piave. Piano d'Azione per l'Energia Sostenibile ed il Clima-PAESC; Comune di San Donà di Piave: San Donà di Piave, Italy, 2020.

39. Maragno, D.; Musco, F.; Domenico, P. La Gestione del Rischio di Ondate di Calore e Allagamenti in Ambiente Urbano: Un Modello Applicativo, Atti della XX Conferenza Nazionale SIU. Urbanistica e/è Azione Pubblica. La Responsabilità della Proposta; SIU-Società Italiana Degli Urbanisti: Milan, Italy, 2017; pp. 131-140.

40. Musco, F.; Zanchini, E. (Eds.) Il Clima Cambia le Città: Strategie di Adattamento e Mitigazione Nella Pianificazione Urbanistica; Franco Angeli: Milan, Italy, 2014.

41. Musco, F. (Ed.) Counteracting Urban Heat Island Effects in a Global Climate Change Scenario; Springer: Charm, Switzerland, 2016.

42. Tucci, F. Adattamento ai Cambiamenti Climatici di Architetture e Città 'Green' per Migliorare la Resilienza Dell'ambiente Costruito. Minacce, Vulnerabilità, Rischi. Assi Strategici, Indirizzi, Azioni D'intervento; Report presentato alla 2a Conferenza Nazionale delle Green City, Milano, 16 luglio 2019; Susdef Pubblicazioni: Roma, Italy, 2019.

43. Magni, F. Climate Proof Planning: L'adattamento in Italia tra Sperimentazioni e Innovazioni; FrancoAngeli: Milan, Italy, 2019.

44. Fritzsche, K.; Schneiderbauer, S.; Bubeck, P.; Kienberger, S.; Buth, M.; Zebisch, M.; Kahlenborn, W. The Vulnerability Sourcebook: Concept and Guidelines for Standardised Vulnerability Assessments; Deutsche Gesellschaft für Internationale Zusammenarbeit (GIZ) GmbH: Bonn, North Rhine-Westphalia, Germany, 2014.

45. Romero Lankao, P.; Zwickel, T. A conceptual framework for an urban areas typology to integrate climate change mitigation and adaptation. Urban Clim. 2014, 14, 116-137.

46. O'Brien, K.; Eriksen, S.; Nygaard, L.P.; Schjolden, A. Why different interpretations of vulnerability matter in climate change discourses. Clim. Policy 2007, 7, 73-88. [CrossRef]

47. Stewaed, D.; Oke, T.R. Evaluation of the 'local climate zone' scheme using temperature observations and model simulations. Int. J. of Climatol. 2014, 34, 1062-1080.

48. Maragno, D. Ict, Resilienza e Pianificazione Urbanistica. Per Adattare le Città al Clima; FrancoAngeli: Milan, Italy, 2018.

Publisher's Note: MDPI stays neutral with regard to jurisdictional claims in published maps and institutional affiliations. 